\title{
Extrastriatal dopaminergic circuits of the basal ganglia
}

\author{
Karen S. Rommelfanger ${ }^{1}$ and Thomas Wichmann ${ }^{1,2 *}$ \\ Yerkes National Primate Research Center, Emory University, Atlanta, GA, USA
}

2 Department of Neurology, Emory University, Atlanta, GA, USA

\section{Edited by:}

Jose L. Lanciego, University of

Navarra, Spain

\section{Reviewed by:}

Veronica Martinez-Cerdeno, University of California at Davis, USA

Tomas Gonzalez-Hernandez, University of La Laguna, Spain

*Correspondence:

Thomas Wichmann, Yerkes National Primate Research Center, Emory

University, 954 Gatewood Road, NE,

Atlanta, GA 30329, USA.

e-mail: twichma@emory.edu
The basal ganglia are comprised of the striatum, the external and internal segment of the globus pallidus (GPe and GPi, respectively), the subthalamic nucleus (STN), and the substantia nigra pars compacta and reticulata (SNc and $\mathrm{SNr}$, respectively). Dopamine has long been identified as an important modulator of basal ganglia function in the striatum, and disturbances of striatal dopaminergic transmission have been implicated in diseases such as Parkinson's disease (PD), addiction and attention deficit hyperactivity disorder. However, recent evidence suggests that dopamine may also modulate basal ganglia function at sites outside of the striatum, and that changes in dopaminergic transmission at these sites may contribute to the symptoms of PD and other neuropsychiatric disorders. This review summarizes the current knowledge of the anatomy, functional effects and behavioral consequences of the dopaminergic innervation to the GPe, GPi, STN, and SNr. Further insights into the dopaminergic modulation of basal ganglia function at extrastriatal sites may provide us with opportunities to develop new and more specific strategies for treating disorders of basal ganglia dysfunction.

Keywords: subthalamic nucleus, globus pallidus, substantia nigra, Parkinson's disease, basal ganglia, dopamine, GABA glutamate

\section{INTRODUCTION}

The basal ganglia consist of the striatum, the external and internal segment of the globus pallidus (GPe and GPi, respectively), the subthalamic nucleus (STN), and the substantia nigra pars compacta and reticulata ( $\mathrm{SNc}$ and $\mathrm{SNr}$, respectively). It is well known that the functions of these structures are strongly modulated by the neuromodulator dopamine. The striatum has long been the focus of investigation into dopamine's effects on basal ganglia function, as the dopamine concentration in this nucleus surpasses that in other basal ganglia nuclei. Recent research has demonstrated that dopamine is also present in basal ganglia areas outside of the striatum, and has strong effects on the neuronal activities in these nuclei. In this review we will first briefly describe relevant features of the general circuit anatomy of the basal ganglia, followed by a summary of the current state of our knowledge of the anatomical and functional features of the dopamine supply to the extrastriatal basal ganglia.

\section{CIRCUIT ANATOMY OF THE BASAL GANGLIA}

The basal ganglia are components of larger functionally and anatomically segregated circuits that also involve the cerebral cortex and thalamus (Alexander et al., 1986, 1990; Hoover and Strick, 1993; Middleton and Strick, 1997, 2002; Kelly and Strick, 2004; Mallet et al., 2007; Wichmann and Delong, 2007). The "motor" circuit originates in the frontal cortical motor areas and involves motor portions of the striatum, GPe, STN, GPi, SNr, and thalamus, returning to the frontal cortex. "Associative" and "limbic" circuits originate from the prefrontal associative and limbic cortices and involve related areas in the basal ganglia and thalamus separate from those occupied by the motor circuit. While the motor circuit is thought to be involved in the control of movement, the associative circuit may play a role in the control of executive functions, and the limbic circuit in the control of emotions and motivation. Dysfunction in elements of these circuits may contribute to diseases ranging from classical movement disorders, such as Parkinson's disease (PD), to neuropsychiatric conditions, such as Tourette syndrome or addiction.

The anatomy of individual connections within these circuits has been described in considerable detail. Within the basal ganglia, the striatum and STN serve as input stations, while GPi and SNr serve as output stations. Glutamatergic efferents from cortex and thalamus project to the striatum and STN in a topographically organized manner (Alexander et al., 1986, 1990; Middleton and Strick, 2002; Kelly and Strick, 2004; Mallet et al., 2007; Wichmann and Delong, 2007). The input and output nuclei of the basal ganglia are connected through two main pathways, i.e., the monosynaptic GABAergic "direct" pathway and polysynaptic "indirect" pathway. The indirect pathway involves GABAergic projections from the striatum to GPe and from GPe to the STN, as well as excitatory glutamatergic projections from the STN to GPe, GPi, and SNr.

At the most basic level of analysis, the polarities of the connections within the direct and indirect pathways oppose one another. Activation of the striatal neurons of the direct pathway have predominately net inhibitory effects on GPi/SNr activity, while activation of the striatal neurons of the indirect pathway have net excitatory effects on them. This scheme is too simplistic, however, as the interactions between and within the two pathways may shape firing patterns independent of firing rates (e.g., oscillatory and burst patterns of discharge, in the GPi/SNr; Galvan and Wichmann, 2008).

The GPi and SNr send topographically organized GABAergic projections to the thalamus and brainstem. Motor circuit output from the GPi and SNr reaches the anterior portion of the ventrolateral thalamic nucleus (VLa), which then project back 
to motor areas of the frontal cortex. In contrast, associative circuit output from the $\mathrm{SNr}$ and GPi, reaches the thalamic ventral anterior (VA) nucleus, which sends efferents to the dorsolateral prefrontal cortex and the lateral orbitofrontal cortices (Hoover and Strick, 1993; Haber et al., 1995; Kaneda et al., 2002; Romanelli et al., 2005). Collaterals of the GPi/SNr projection to the ventral thalamus reach the intralaminar thalamic centromedian and parafascicular nuclei (CM/PF), as well as brain stem targets such as the pedunculopontine nucleus, and the reticular formation (Smith et al., 2009).

\section{STRIATAL ACTIONS OF DOPAMINE}

It has been known for many decades that the neurotransmitter dopamine is present in high concentrations in the basal ganglia. The dopamine supply to these structures originates in the midbrain dopaminergic nuclei, the SNc and ventral tegmental area. The striatum is the most prominent release site for dopamine in the basal ganglia, influencing the overall balance of activity along the direct and indirect pathways via different types of dopamine receptors (Gerfen et al., 1990). D1-like receptors (D1LR, including D1- and D5-receptors; Clark and White, 1987; Neve, 1997) are found on striatal neurons that give rise to the direct pathway, while D2-like receptors (D2LRs, including D2-, D3-, and D4-receptors; Neve, 1997) are found on striatal neurons that give rise to the indirect pathway (see, for instance, recent studies in transgenic mice; Heintz, 2001; Day et al., 2006; Wang et al., 2006). Activation of D1LRs on direct pathway neurons is thought to facilitate corticostriatal transmission, while activation of D2LRs on indirect pathway neurons appears to reduce corticostriatal transmission (Gerfen et al., 1990; Gerfen, 1995). According to traditional models of the basal ganglia, the dopamine-mediated increase in activity of the inhibitory direct pathway, in conjunction with the dopamine-mediated reduction of activity in the net excitatory indirect pathway leads to an overall reduction of activity of GPi/SNr neurons, acting to disinhibit thalamocortical projection neurons. In addition to the regulation of transmission along direct and indirect pathways, striatally released dopamine is also implicated in the modulation of learning and neuronal plasticity through processes such as long-term depression (LTD) or potentiation (LTP), acting at glutamatergic synapses (Aosaki et al., 1994; Cragg, 2003; Picconi et al., 2003; Wang et al., 2006; Calabresi et al., 2007; Kreitzer and Malenka, 2007; Schultz, 2007; Flajolet et al., 2008; Kreitzer and Malenka, 2008; Pawlak and Kerr, 2008).

The duration of action and diffusion of dopamine are to some extent regulated by dopamine transporter- (DAT-) mediated uptake (Blakely and Bauman, 2000; Cenci and Lundblad, 2006; Rice and Cragg, 2008). In rodent studies, it has been shown that DAT concentrations and dopamine clearance rates differ among striatal territories, with a dorso-ventral gradient (Missale et al., 1985; Kuhr et al., 1986; Stamford et al., 1988; Letchworth et al., 2001). Given the topographical organization of the striatum, such differences may affect the physiologic role and significance of dopamine in different behavioral domains. For instance, physiological data indicate that the time course of DA signaling may determine the pattern of dopamine-glutamate interaction in different areas of the striatum (Calabresi et al., 2000; Wickens et al., 2003).

\section{EXTRASTRIATAL ACTIONS OF DOPAMINE EXTERNAL PALLIDAL SEGMENT \\ Anatomical studies}

The GPe is a component of the indirect pathway, receiving GABAergic inputs from the striatum (Chang et al., 1981; Filion and Tremblay, 1991; Sidibe and Smith, 1996; Raz et al., 2000), and sending GABAergic projections to STN, GPi, and SNr (Moriizumi et al., 1992; Parent and Hazrati, 1995a,b). Several studies have shown that the primate globus pallidus (GP) receives dopaminergic inputs that are differentially distributed in GPe and GPi, with dopamine fibers arborizing profusely in the GPi and more sparsely in dorsal portion of the GPe (Parent and Smith, 1987; Lavoie et al., 1989; Parent et al., 1989; Hedreen, 1999). Some of these fibers are passing through the pallidum en route to the striatum. However, retrograde and anterograde labeling studies in rats and monkeys have shown that at least some of these fibers arise as a nigropallidal projection that is separate from the nigrostriatal projection (Fallon and Moore, 1978; Lindvall and Bjorklund, 1979; Smith et al., 1989; Gauthier et al., 1999; Jan et al., 2000; Smith and Kieval, 2000; Anaya-Martinez et al., 2006). Low levels of dopamine (Pifl et al., 1990) as well as DAT immunoreactivity and DAT ligand binding have also been detected in postmortem studies on human GPe tissue (Ciliax et al., 1999; Porritt et al., 2005) and rodent GP, the rodent homologue of the primate GPe (Ciliax et al., 1995; Coulter et al., 1995) indicating the presence of terminals of a dopaminergic projection in the GPe.

Dopamine receptors are found at pre- and postsynaptic locations in GPe (Table 1). Most of the presynaptic dopamine receptors are thought to be D2LRs, and are located on terminals of the GABAergic striatopallidal projection (Parent and Smith, 1987; Gerfen et al., 1990; Deng et al., 2006). Using electron microscopy we recently confirmed the presence of presynaptic D2-receptors in the monkey GPe on putatively GABAergic axons and terminals, with sparse labeling of putatively glutamatergic terminals (unpublished observation). A previous rat study identified D4-receptors primarily on axons and on a few putatively glutamatergic terminals in GP (Rivera et al., 2003).

There is also evidence for postsynaptic expression of D2LRs in GPe. For example, D2- and (less) D3-receptor mRNA has been found in the human GPe (Murray et al., 1994). However, another study did not confirm D3-receptor mRNA expression in monkeys (Quik et al., 2000). In rats, D2-receptor mRNA was found, particularly in pallidal cells projecting to the striatum (Marshall et al., 2001; Hoover and Marshall, 2004). Low levels of D2-receptor protein labeling have been detected in human GPe (Levey et al., 1993) and in postsynaptic structures in the rat (Yung et al., 1995). Scattered cell bodies in the rat GP showed immunoreactivity for D2-, D3-, and D4-receptor (Khan et al., 1998). In the monkey, both D3- (Quik et al., 2000) and D4-receptors (Mrzljak et al., 1996) have been found. The latter are associated with the parvalbuminpositive GABAergic neurons which project predominantly to the basal ganglia output nuclei (Mrzljak et al., 1996).

In addition to these D2LRs, lower levels of D1LRs have been detected, in axons and terminal boutons forming symmetric, putatively GABAergic synapses in the rodent GP (Levey et al., 1993; Yung et al., 1995). D5-receptors were identified in the rodent GP and monkey GPe (Ciliax et al., 2000; Khan et al., 2000). 
Table 1 | Dopamine receptor localization in the extrastriatal basal ganglia.

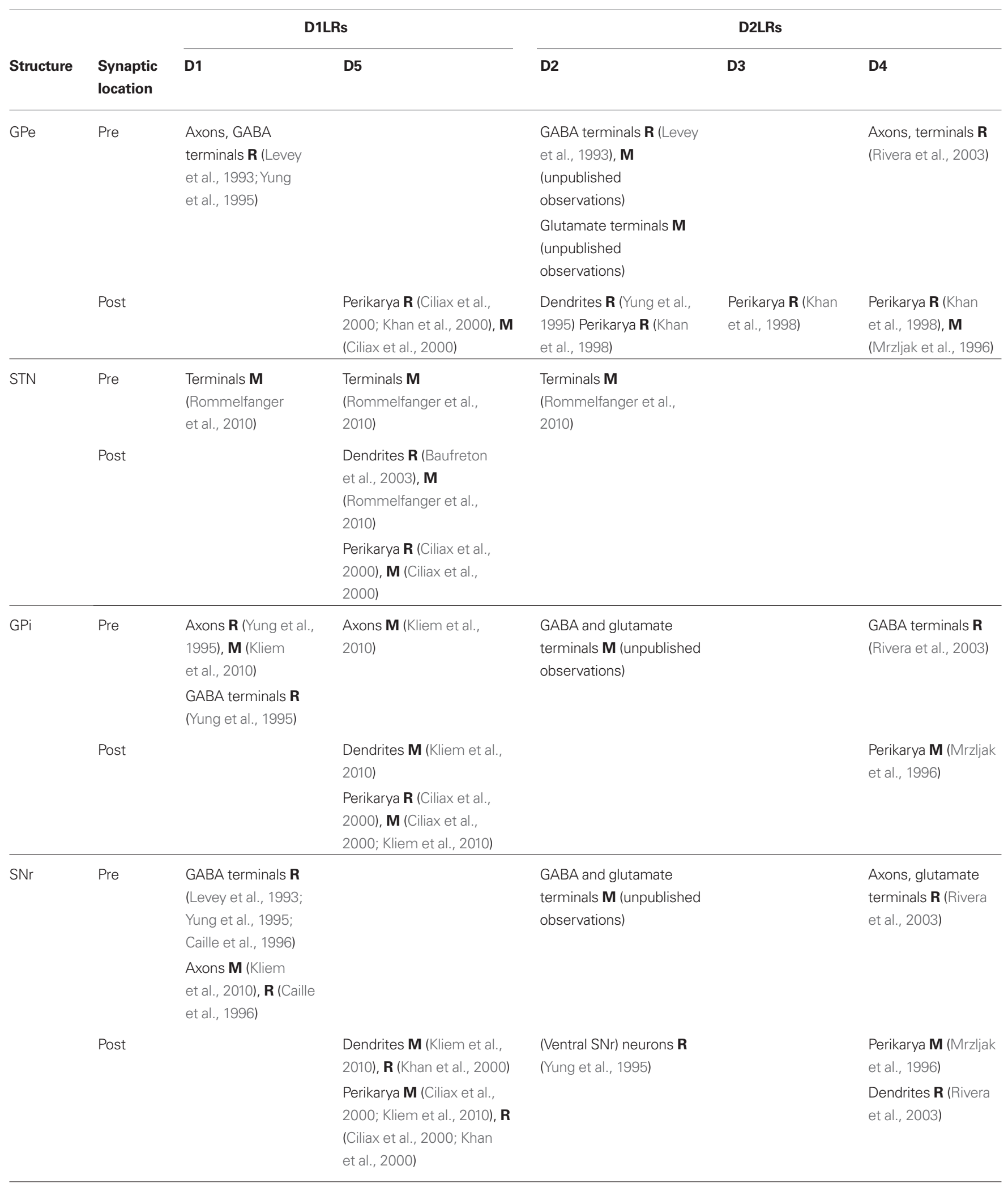

Only studies verifying the presence of receptor protein are included in this table.

$H$, human; $M$, monkey; $R$, rodent. 


\section{Functional studies}

Substantia nigra pars compacta lesions in rodents and monkeys reduce dopamine levels in GPe (Parent et al., 1990; Jan et al., 2000; Fuchs and Hauber, 2004). Furthermore, in vivo microdialysis studies in rats have shown that dopamine is released in the GP, that local administration of high-potassium solutions increases dopamine concentrations in pallidal dialysates, and that the release is inhibited by reverse dialysis of the sodium channel blocker tetrodotoxin, or by the use of low-calcium-medium, supporting the notion that dopamine is released in a spike-dependent fashion at this site (Dewar et al., 1987; Pifl et al., 1990; Hauber and Fuchs, 2000).

Given the predominance of D2LRs in GPe, it is likely that most actions of dopamine in GPe are mediated via D2LRs. Activation of pallidal D2LRs has been shown to increase the activity of GPe neurons (see Table 2). For instance, activation of D2LRs in the rat GP increases the expression of the immediate early gene c-fos (Billings and Marshall, 2003), and infusions of the non-specific dopamine receptor agonist apomorphine into the rat GP increases pallidal neuron activity (Napier et al., 1991). Our recent studies in primates have also demonstrated that the neuronal activity in GPe was increased after intra-GPe infusions of the D2LR agonist quinpirole (Hadipour Niktarash et al., 2008), and that infusions of the D2LR antagonist sulpiride lowered pallidal firing rates, suggesting that the pallidal D2LRs are occupied by endogenous dopamine under normal conditions (unpublished observations).

While some of the pallidal effects of D2LR ligands may be mediated by postsynaptic D4-receptors (Shin et al., 2003), most of them are likely due to presynaptic modulation of GABAergic transmission. GABA release in GPe originates from terminals of the "indirect" striatopallidal pathway, and from local axon collaterals of pallidal neurons (Parent et al., 1999, 2000; Kita et al., 2004). Given the high activity levels of pallidal neurons (DeLong, 1971; Anderson and Horak, 1985; Miller and DeLong, 1987; Tremblay et al., 1989; Matsumura et al., 1995; Nambu et al., 2000; Raz et al., 2001; Kita et al., 2004; Starr et al., 2005), it is likely that most of the pallidal GABA stems from local axon collaterals. To what extent collateral interactions influence pallidal activities remains unclear. Early studies in anesthetized rats showed that iontophoresis of dopamine or of amphetamine, a dopamine releasing agent, reduces GABAergic transmission in the pallidum (Bergstrom and Walters, 1984). Microdialysis studies showed that activation of D2LRs decreased GABA release in the rat GP while activation of D1LRs increased GABA release (Floran et al., 1990, 1997). Subsequent patch clamp recordings of GP neurons in rat brain slice demonstrated that activation of presynaptic D2LRs decreases GABA-A receptor-mediated currents in the pallidum (Cooper and Stanford, 2001).

Dopamine receptor activation may also modulate the glutamatergic inputs to the GPe from the STN (Kita and Kitai, 1987; Robledo and Feger, 1990; Smith et al., 1990; Hazrati and Parent, 1992; Shink et al., 1996; Nambu et al., 2000) or CM/PF (Mouroux et al., 1997; Yasukawa et al., 2004). In vitro patch clamp studies in rodent brain slices have suggested that activation of presynaptic D1LRs facilitates glutamate release (Hernandez et al., 2007) while activation of D2LRs reduces it (Hernandez et al., 2006). These effects are not mutually exclusive, indicating that the involved receptors may be located on different axon terminals.

\section{Studies of behavioral effects}

In general, activation of D1LRs or D2LRs in the rodent GP appears to facilitate movement. In support of this notion, local intra-pallidal infusions of D1LR or D2LR antagonists were found to induce akinesia in rats, likely by blocking the effects of endogenous dopamine on these receptors (Hauber and Lutz, 1999). Similarly, intra-pallidal infusion of D1LR agonists (Sanudo-Pena and Walker, 1998) increased general movement. Other studies have demonstrated that infusion of D1LR agonists, D2LR agonists (Koshikawa et al., 1990), or amphetamine (Costall et al., 1972a,b) induces stereotypic jaw movements. The behavioral effects of dopamine receptor activation in the GPe have not been examined in other species.

\section{SUBTHALAMIC NUCLEUS \\ Anatomical studies}

The STN consists of glutamatergic neurons that send most of their projections to GPe, GPi, and SNr (Smith and Parent, 1988). The activity of STN cells is strongly regulated by its afferents, including inhibitory GABAergic inputs from the GPe and glutamatergic inputs from the cerebral cortex (Mink, 1996; Nambu et al., 1996, 2002; Takada et al., 2001). Smaller projections from the intralaminar nuclei of the thalamus to the STN have also been described (Sugimoto et al., 1983; Lanciego et al., 2004).

Anatomical studies have demonstrated that the STN receives sparse collaterals from the nigrostriatal pathway which pass the nucleus at its dorsal surface (Lavoie et al., 1989; Hedreen, 1999; Augood et al., 2000; Francois et al., 2000). These inputs form symmetric synapses on dendrites of STN neurons in rats (Cragg et al., 2004) and monkeys (Smith and Kieval, 2000). In postmortem human brains, terminal-like tyrosine hydroxylase-positive elements were identified along the STN's dorsal surface (Cossette et al., 1999). Anatomical studies using retrograde (Rinvik et al., 1979; Campbell et al., 1985; Francois et al., 2000) or anterograde tracers (Hassani et al., 1997; Gauthier et al., 1999; Francois et al., 2000) in rats and monkeys support the existence of an SNc-STN projection. Others have detected DAT binding in the rodent STN (Coulter et al., 1995) and found that DAT blockade in rodent slices of STN increases dopamine release as measured by voltammetry (Cragg et al., 2004). We have also noted low levels of DAT immunoreactivity in the monkey STN (unpublished observations) suggesting that dopamine terminals may be found in the STN.

Dopamine receptors exist in the STN (Smith and Kieval, 2000; Smith and Villalba, 2008), but their distribution and relative expression level need further investigation (Table 1). Receptor binding studies have demonstrated D1LRs in the rat and human STN (Boyson et al., 1986; Dawson et al., 1986, 1988; Mansour et al., 1992; Parry et al., 1994; Augood et al., 2000). Similarly, binding studies using ligands for D2LRs (Bouthenet et al., 1987; Johnson et al., 1994), or ligands preferring D1-, D2-, D3-, or D4-receptors (Flores et al., 1999) have detected binding targets in the rat STN. Using electron microscopy, we have recently identified presynaptic D1- and D2-receptors in the monkey STN (Rommelfanger et al., 2010).

The available data on dopamine receptor mRNA is contradictory, but suggest that a portion of the dopamine receptors in the STN are postsynaptically expressed. Several authors have described the presence of the mRNA for D1-, D2-, and D3-receptors (Flores et al., 
Table 2 | Functional effects of dopamine receptor agonists.

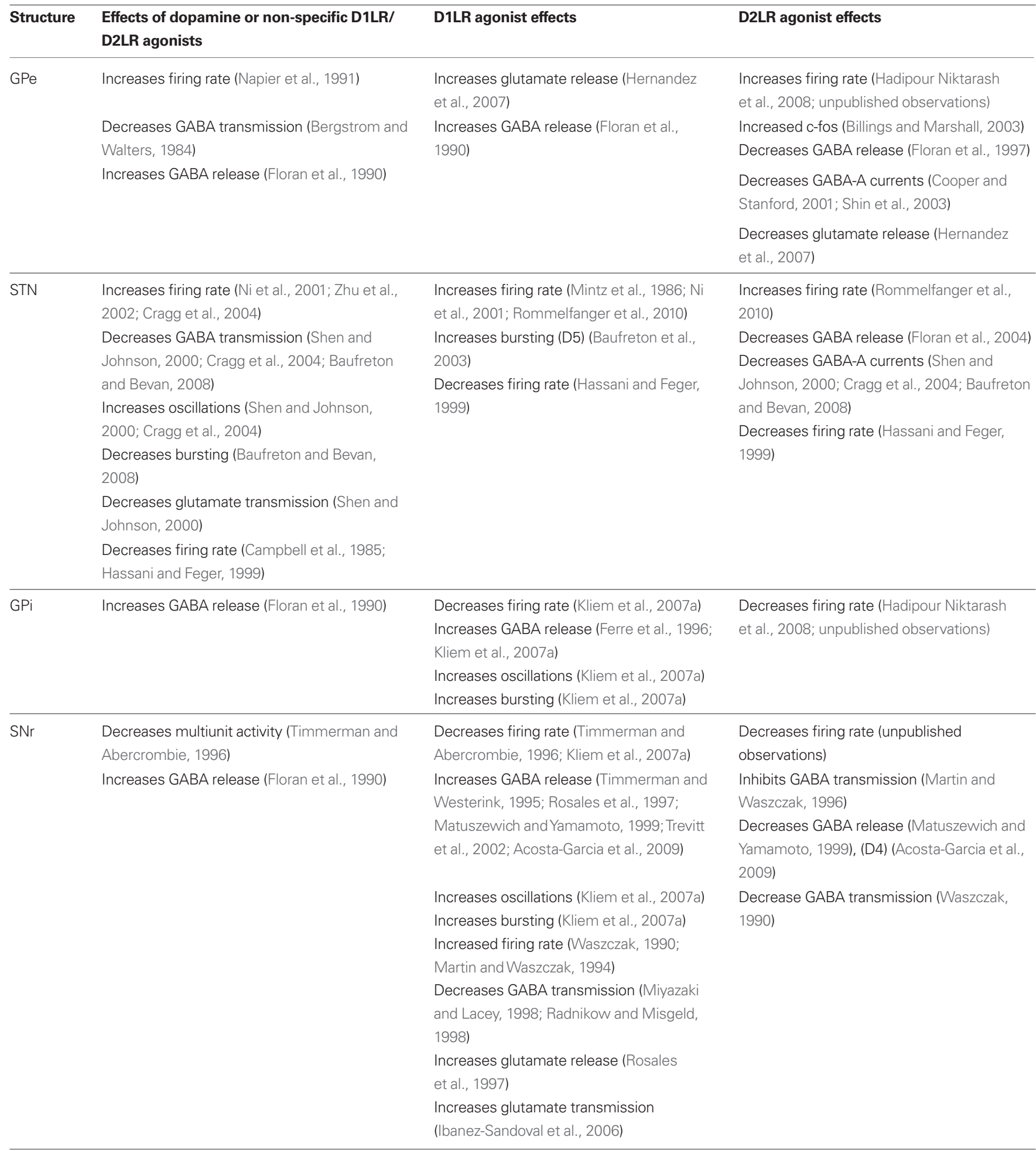

1999), and for D5-receptors in the rat STN (Svenningsson and Le Moine, 2002; Baufreton et al., 2003). Other studies have confirmed the expression of modest amounts of mRNA for D2-receptors, but not of D1-receptors (Mansour et al., 1992; Hurd et al., 2001) or D3-receptors (Quik et al., 2000). Neither D1- nor D2-receptor
mRNA expression was found in the human STN (Augood et al., 2000). Postsynaptic D5-receptor protein expression has been identified at the light and electron microscope level in rats and monkeys (Ciliax et al., 2000; Baufreton et al., 2003; Rommelfanger et al., 2010). 


\section{Functional studies}

Early studies of dopamine receptor activation in the STN suggested that dopamine receptor activation in the STN may act to decrease STN neuronal activity. Campbell et al. (1985) showed that iontophoretic application of dopamine or apomorphine in vivo decreased the activity of most STN neurons, while the nonspecific dopamine receptor antagonist haloperidol increased neuronal firing. Other in vivo studies showed that microinjections of apomorphine or agonists acting at D1LRs or D2LRs into the STN reduced STN firing (Hassani and Feger, 1999). In vitro brain slice recording studies showed that dopamine reduces glutamatergic currents in the STN (Shen and Johnson, 2000).

However, more recent studies have supported the view that dopamine facilitates rather than inhibits neuronal firing in the STN (Table 2), via actions on D1LRs and D2LRs. Thus, activation of postsynaptic D1LRs were shown to increase STN activity (Baufreton et al., 2005a). This was specifically demonstrated for postsynaptic D5-receptors whose activation appears to potentiate burst firing in a subgroup of STN neurons (Baufreton et al., 2003).

There is also strong evidence for D2LR-mediated facilitation of STN activity. These may involve postsynaptic effects, as demonstrated by Zhu et al. (2002), but also prominent activation of presynaptic D2LRs. For example, activation of D2LRs in the STN was shown to reduce GABA-A receptor-mediated currents in STN neurons by reducing GABA release (Shen and Johnson, 2000; Floran et al., 2004). Studies by Cragg et al. (2004) showed that dopamine release occurs in the STN, and that dopamine depolarizes neurons, increases spontaneous spike generation, and reduces the magnitude and frequency of evoked GABA-A receptor-mediated inhibitory postsynaptic potentials in the STN. More recent in vitro brain slice recording studies confirmed that D2LR activation increases STN activity via a reduction of GABA release, and that this may result not only in firing rate changes, but also in a reduction of rebound bursting activities in this nucleus (Baufreton and Bevan, 2008; Johnson, 2008). Baufreton et al. (2005b) have proposed that the combined actions of dopamine on D1LRs and D2LRs on STN cells leads to increased firing and reduced bursting in most STN neurons (see also section on the effects of dopamine depletion below).

Facilitatory effects of dopamine receptor activation have also been demonstrated in several in vivo studies. For example, intra-subthalamic infusions of dopamine or of the D1LR agonist SKF38393 activated STN neurons in rats (Mintz et al., 1986; Ni et al., 2001). We have recently carried out preliminary studies indicating that activation of D1LRs or D2LRs in the monkey STN increases the firing rates of STN neurons, and that D1LR activation decreases bursting activities of these neurons (Rommelfanger et al., 2010).

The discrepancy between studies demonstrating inhibitory and facilitatory effects of dopamine in the STN may in part be explained by differences in the location of the recorded neurons within the STN, the choice of anesthetics, or the pharmacological properties of the drugs used in these studies. For example, dopamine binds with higher affinity to D3-, D4-, and D5-receptors than to D1-receptors (Sunahara et al., 1991; Missale et al., 1998), and SKF38393 is a partial rather than full agonist at D1LRs (Twery et al., 1994; Kreiss et al., 1996; Gleason and Witkin, 2004), complicating the interpretation of some of the earlier studies.

\section{Studies of behavioral effects}

Few studies have investigated the behavioral effects of dopamine receptor ligands in the STN. The available studies suggest that agents acting at D1LRs have stronger behavioral effects than agents acting at D2LRs. Activation of D1LRs in the STN resulted in orofacial dyskinesias in normal and dopamine-depleted rats (Parry et al., 1994; Mehta et al., 2000). In normal animals, bilateral STN infusions of D1LR- but not D2LR antagonists induced catalepsy in one study (Hauber, 1998). No such information is available from primate experiments.

\section{INTERNAL PALLIDAL SEGMENT Anatomical studies}

GPi activity is indirectly under the control of dopamine released in the striatum, via the direct and indirect pathways. In addition, the primate GPi receives its own diffusely arborizing dopaminergic input (Parent and Smith, 1987; Lavoie et al., 1989; Parent et al., 1989; Hedreen, 1999), as demonstrated through the detection of dopamine in GPi (Pifl et al., 1990; Hornykiewicz, 1998), by the presence of DAT in ligand binding studies, and through immunohistochemical investigations on human postmortem tissue (Marcusson and Eriksson, 1988; Ciliax et al., 1999; Porritt et al., 2005), monkey (Gnanalingham et al., 1995) GPi and in the rodent entopeduncular nucleus, the rat homologue to the monkey GPi (Ciliax et al., 1995; Coulter et al., 1995). Retrograde and anterograde tract tracing studies in rodents and monkeys have demonstrated that dopaminergic terminals in GPi do not arise from collaterals of the nigrostriatal tract, but from a separate population of SNc neurons that directly innervate the GPi (Fallon and Moore, 1978; Lindvall and Bjorklund, 1979; Smith et al., 1989; Parent et al., 1990; Schneider and Dacko, 1991; Gauthier et al., 1999; Jan et al., 2000).

Most of the available evidence suggests that dopaminergic effects in GPi are primarily mediated via D1LRs (Table 1). In rats, D1LR binding (Fremeau Jr. et al., 1991) and D1-receptor protein (Levey et al., 1993; Yung et al., 1995) were found in the entopeduncular nucleus (the rat homologue to the monkey GPi), predominately at presynaptic locations, on axons and putatively GABAergic terminals. In primates, receptor binding studies have demonstrated the presence of D1LRs in GPi (Richfield et al., 1987; Besson et al., 1988), which was recently confirmed by our ultrastructural studies (Kliem et al., 2010). Most of the D1- and D5-receptor labeling was found in unmyelinated pre-terminal axons, with additional postsynaptic D5-receptor labeling in dendrites and glial processes in rodents and monkeys (Ciliax et al., 2000; Kliem et al., 2010).

Receptor binding studies have demonstrated that the level of D2LRs is much lower than that of D1LRs in the primate GPi (Richfield et al., 1987; Besson et al., 1988). D3-receptor binding (but not mRNA) was also demonstrated in the monkey GPi (Quik et al., 2000), and D2- and D3-receptor mRNA and binding sites have been identified in the human GPi (Gurevich and Joyce, 1999). Studies in rats and monkeys have documented D4-receptor protein in the GPi (Mrzljak et al., 1996; Rivera et al., 2003). Using electron microscopy, we recently found that D2-receptors in the monkey GPi are almost exclusively presynaptic, with some receptors at presumably glutamatergic (i.e., forming asymmetric synapses) terminals (unpublished observations). Experiments in D2-receptor knockout mice have suggested that at least some of the presynaptic D2-receptors are 
autoreceptors (Mercuri et al., 1997; Koeltzow et al., 1998). Presynaptic D4-receptors in the rat entopeduncular nucleus may be located on GABAergic striatopallidal terminals (Rivera et al., 2003).

\section{Functional studies}

Overall, dopamine appears to decrease the neuronal activity in the GPi, likely via activation of D1LRs (Table 2). We found that microinjections of a D1LR agonist into the monkey GPi reduces GPi firing rates, and increases neuronal burst discharges and oscillatory firing in the $3-15 \mathrm{~Hz}$ range of frequencies. Interestingly, blockade of D1LRs in these studies resulted in increased spontaneous neuronal activity, suggesting that the D1LRs are occupied by endogenous dopamine under normal conditions (Kliem et al., 2007a). Because most D1LRs are found presynaptically on putatively GABAergic terminals (see above), it is likely that the D1LR agonist infusions into GPi acted through a facilitation of GABA release. Microdialysis studies have, in fact, directly shown that GABA levels in the entopeduncular nucleus (in rats) or GPi (in monkeys) increase in response to activation of D1LRs (Ferre et al., 1996; Kliem et al., 2007a), and that GABA release is reduced upon D1LR antagonist administration (Floran et al., 1990). Increased GABA levels may act to hyperpolarize GPi cells, lowering GPi firing and triggering rebound bursts, as in GPe and STN (Nambu and Llinas, 1994; Overton and Greenfield, 1995; Beurrier et al., 1999; Bevan et al., 2002; Kass and Mintz, 2006). The source(s) of the GABAergic inputs whose activity is regulated via D1LRs in GPi is not entirely certain, but it is likely that these fibers originate largely from the striatal medium spiny neurons that give rise to the direct pathway. Activation of postsynaptic D5-receptors and subsequent activation of GPi cells may also occur, counteracting some of the changes in GABA release induced by presynaptic D1LR activation.

There is relatively little evidence supporting D2LR-mediated effects in GPi. Peripheral administration of D2LR agonists decreases neuronal firing in human GPi cells (Hutchinson et al., 1997). Peripheral exposure to D2LR antagonists increases Fos-like immunoreactivity in the entopeduncular nucleus in normal rats (Wirtshafter and Asin, 1995), and reduces firing abnormalities in the entopeduncular nucleus in parkinsonian animals (Ruskin et al., 2002). It is likely that these drug effects are in large part secondary to activation or inactivation of striatal D2LRs, and are transmitted to GPi via the indirect pathway. In our recent experiments in monkeys, local activation of D2LRs in the GPi also resulted in decreased firing rates (Hadipour Niktarash et al., 2008), and blockade of these receptors increased firing rates (unpublished observations). The results of these local microinjection studies can perhaps be explained through activation of presynaptic D2LRs on glutamatergic terminals, although other mechanisms of action cannot be excluded.

\section{Studies of behavioral effects}

Very few studies have examined the behavioral effects of dopamine receptor activation in the GPi. Studies in human subjects have indicated that decreased dopamine levels in GPi, as measured with raclopride displacement positron emission tomography (PET), were associated with faster motor learning (Garraux et al., 2007). Studies using (18)F-DOPA PET in patients with PD suggested that pallidal (18)F-DOPA uptake may be increased in early stages of the disease, perhaps as a compensatory change (Whone et al., 2003).

\section{SUBSTANTIA NIGRA PARS RETICULATA Dopamine release in the $\mathrm{SNr}$}

Studies in the 1970s showed that dopamine release in the substantia nigra differs from that in the other basal ganglia nuclei in that the release is dendritic, rather than axonal (Korf et al., 1976; Leviel et al., 1979). Dendrites of SNc neurons may supply dopamine to $\mathrm{SNr}$ neurons from up to several hundred microns away, (Bjorklund and Lindvall, 1975; Nieoullon et al., 1978; Arsenault et al., 1988; Hausser et al., 1995). There continues to be debate regarding some of the characteristics of dendritic dopamine release. For instance, some studies have documented that dendritic release can be reduced by blockade of sodium channels with tetrodotoxin (Araneda and Bustos, 1989; Santiago and Westerink, 1991; Westerink et al., 1994; Cragg and Greenfield, 1997), and increased by depolarizing agents (Rice et al., 1994), and that release is calcium-dependent (Ford et al., 2010), suggesting that it may be mediated by action potentials. However, other authors concluded that the dendritic release of dopamine in the $\mathrm{SNr}$ is independent of action potentials (Robertson et al., 1991) and not stimulated by amphetamine (Bernardini et al., 1991; Robertson et al., 1991; Hoffman and Gerhardt, 1999; Gerhardt et al., 2002).

Another area of disagreement pertains to the question whether nigral dopamine release is vesicular. Early studies did not identify storage vesicles for dopamine in SNc dendrites (Reubi and Sandri, 1979; Wassef et al., 1981), but more recent studies have reported otherwise. Pleiomorphic vesicles have been detected in the symmetrical dendrodendritic synapses of SNc neurons (Groves and Linder, 1983) and have been shown more recently to express the vesicular monoamine transporter (Nirenberg et al., 1996). Vesicular storage of dopamine at the level of the $\mathrm{SN}$ is also supported by evidence that the nigral release of dopamine is sensitive to reserpine, a compound that depletes vesicular dopamine pools (Elverfors et al., 1997), as well as compounds that interfere with vesicular fusion and release (i.e., the $25 \mathrm{kDa}$ synaptosome-associated protein SNAP-25; Bergquist et al., 2002). In addition, dendritic dopamine signaling can be terminated via the DAT as DAT blockade can enhance nigral dopamine levels (Robertson et al., 1991; Santiago and Westerink, 1992; Cragg et al., 1997; Cragg et al., 2001). Dendritic DAT immunoreactivity in $\mathrm{SNc}$ and $\mathrm{SNr}$ has been detected in rodent (Nirenberg et al., 1996) and human tissue (Ciliax et al., 1999).

\section{Anatomical studies}

Receptor binding studies (Richfield et al., 1987) and immunohistochemical studies of the distribution of dopamine receptor protein (Levey et al., 1993; Yung et al., 1995; Kliem et al., 2010) have shown that the rat and monkey $\mathrm{SNr}$ contains predominantly pre- and postsynaptic D1LRs (Table 1). D1-receptor immunoreactivity associated with the $\mathrm{SNr}$ was shown to extend into the ventral $\mathrm{SNc}$ (Yung et al., 1995). These receptors have been described as being expressed mostly on putative GABAergic terminals of the direct striatonigral pathway (Levey et al., 1993; Bergson et al., 1995; Yung et al., 1995; Caille et al., 1996; Kliem et al., 2010), supported by the finding that striatal lesions reduce or abolish D1LR binding in the SNr (Beckstead, 1988; Berger et al., 1991). Postsynaptic D1-receptor localization has been suggested, on the basis of the detection of D1-receptor mRNA (Fremeau Jr. et al., 1991). D5-receptors have also been identified in rodents and monkeys in postsynaptic locations (Ciliax et al., 2000; Khan et al., 2000; Kliem et al., 2010). 
There are fewer reports of D2LRs in the $\mathrm{SNr}$ (Table 1). D2-receptor protein has been identified in neurons in the ventral SNr in rats (Yung et al., 1995). Furthermore, mRNA distribution and receptor binding studies have shown D2- and D3-receptors in human SNr neurons (Gurevich and Joyce, 1999). D2-receptors were also detected in cell bodies and dendrites of SNc neurons extending into the SNr (Yung et al., 1995) suggesting that D2 autoreceptors in the SNc may regulate dopamine release within the SNr. We have recently demonstrated the presence of presynaptic D2-receptors in the monkey SNr on putatively GABA- and glutamatergic synapses (unpublished observations). In addition, D4-receptor protein has been identified with electron microscopy in neurons of the monkey SNr (Mrzljak et al., 1996), and at pre- and postsynaptic locations in the rat $\mathrm{SNr}$ (Rivera et al., 2003).

\section{Functional studies}

Most of the available studies in rodents agree that dopamine in the SNr acts primarily at presynaptic D1LRs, and that activation of these receptors reduces SNr firing via facilitation of GABA transmission from striatonigral (i.e., direct pathway) fibers (Table 2). Our recent primate recording experiments have confirmed that the local activation of D1LRs in the SNr reduces the activity of $\mathrm{SNr}$ neurons (Kliem et al., 2007a). Furthermore, local D1LR activation influenced the discharge patterns of SNr neurons, increasing oscillations in the low frequency ranges (3-15 Hz range of frequencies) and increasing bursting (Kliem et al., 2007a,b), perhaps through the induction of rebound bursts due to GABA-mediated hyperpolarization of SNr cells, as has been demonstrated to occur in GPe and STN (Nambu and Llinas, 1994; Overton and Greenfield, 1995; Beurrier et al., 1999; Bevan et al., 2002; Kass and Mintz, 2006). Increased GABA release upon activation of D1LRs was shown in microdialysis studies, and is also supported by electrophysiologic experiments (Floran et al., 1990; Timmerman and Westerink, 1995; Rosales et al., 1997; Radnikow and Misgeld, 1998; Matuszewich and Yamamoto, 1999; Trevitt et al., 2002; Acosta-Garcia et al., 2009). Although it has also been shown that endogenous dopamine inhibits SNr neurons in anesthetized (Timmerman and Abercrombie, 1996) and awake, behaving rats (Windels and Kiyatkin, 2006), we did not find convincing pharmacological evidence for a significant dopaminergic "tone" in our recent primate experiments (Kliem et al., 2007a; unpublished observations).

Not all studies have agreed that the activation of D1LRs increases GABA release and reduces the activity of neurons in the SNr. Presynaptic inhibition of GABA release upon exposure to D1LR agonists was seen by some authors (Martin and Waszczak, 1994; Miyazaki and Lacey, 1998). These data corroborate previous in vivo studies in which the activity of $\mathrm{SNr}$ neurons was increased by iontophoretic application of D1LR agonist in anesthetized rats (Waszczak, 1990). It is possible that some of these excitatory effects of D1LR agonists arose from actions at non-GABAergic sites. For example, there is evidence that D1LR activation in the SNr may increase glutamate released by terminals originating from the STN (Rosales et al., 1997; Ibanez-Sandoval et al., 2006). It remains unclear why such effects were not seen in other studies.

In contrast to the large body of evidence describing the effects of D1LR activation in the SNr, there are few studies examining the effects of D2LR activation. These studies have come to con- tradictory conclusions (see Table 2). In rodents local application of agonists at D2LRs was shown to block the inhibitory effects of striatal stimulation on SNr neurons (Waszczak, 1990; Martin and Waszczak, 1996) and to reduce GABA release (Matuszewich and Yamamoto, 1999). Other studies have shown that activation of nigral D4-receptors inhibits dopamine-induced GABA release in rat brain slices, an effect that was reversed by lesions of the pallidum (Acosta-Garcia et al., 2009). In contrast, we have recently found that injections of the D2LR agonist quinpirole decreases firing rates of neurons in the monkey $\mathrm{SNr}$, which may be explained through an inhibitory effect on glutamatergic afferents from the STN (Hadipour Niktarash et al., 2008).

There is also limited evidence that dendritic dopamine release may inhibit SNc neuron activity, and may, thus, indirectly affect dopamine release in the striatum, presumably resulting in secondary effect on the basal ganglia via direct and indirect pathways (Lacey et al., 1987; Pucak and Grace, 1994).

\section{Studies of behavioral effects}

The activation of dopamine receptors in the rat $\mathrm{SNr}$ has been shown to increase movement. Thus, infusions of agonists at D1LRs into the rodent $\mathrm{SNr}$ result in increased movement, drugseeking behaviors, and an enhanced startle response (Meloni and Davis, 2004). Bilateral infusions of D1LR antagonists into the $\mathrm{SNr}$ were also shown to decrease lever-pressing and general locomotor activity (Jackson and Kelly, 1983a,b; Kelly et al., 1987; Trevitt et al., 2001), while unilateral injection of the D1LR antagonist inhibited amphetamine-induced stereotypies (Yurek and Hipkens, 1993; Lee et al., 1995; Timmerman and Abercrombie, 1996) and induced contralateral circling (Asin and Montana, 1988). In contrast, D1LR and D2LR antagonists impaired rod-balancing performance in normal rats (Bergquist et al., 2003). Irreversible blockade of dopamine receptors in the rat $\mathrm{SNr}$ was shown to increase electromyographic (EMG) activity and may contribute to the development of rigidity in parkinsonism (Crocker, 1995; Hemsley and Crocker, 1998) likely mediated via effects on D1LRs (Hemsley and Crocker, 2001). Depletion of dopamine release from SNc neurons through local intranigral administration of the VMAT2 inhibitor tetrabenazine was shown to impair motor performance in rats without altering striatal dopamine release (Andersson et al., 2006).

\section{EXTRASTRIATAL DOPAMINE LOSS IN PARKINSONISM}

While the degeneration of the dopaminergic nigrostriatal tract is the hallmark pathology of PD, substantial dopamine loss also occurs in basal ganglia areas outside of the striatum in patients with PD and in animal models of the disorder. For instance, a study of dopamine loss in monkeys rendered severely parkinsonian by injections of the dopaminergic neurotoxin 1-methyl-4-phenyl-1,2,3,6-tetrahydropyridine (MPTP) demonstrated that striatal dopamine loss of $>99 \%$ was accompanied by dopamine loss in the extrastriatal basal ganglia of up to $90 \%$ (Pifl et al., 1990). Significant reductions of dopamine in the GP, SNr, and STN were also detected in the postmortem studies on brain tissue from PD patients (Hornykiewicz, 1998). The dopamine loss in PD is accompanied by significant DAT loss in the striatum and, to a lesser extent, extrastriatal regions (Leenders et al., 1990; Porritt et al., 2005). 


\section{GPe}

Loss of the nigropallidal projection has been demonstrated in patients with PD and in animal models of the disorder (Jan et al., 2000). The nigropallidal system may be more strongly affected in MPTP-treated vervet monkeys (Bergman et al., 1994; Jan et al., 2000) than in MPTPtreated macaques (Parent et al., 1990; Schneider and Dacko, 1991). This difference may contribute to the differences in the sensitivities of these species to the effects of MPTP (Pifl et al., 1992). Intra-pallidal infusions of dopamine were shown to partially restore motor deficits in rats whose midbrain dopaminergic system was damaged through infusions of 6-hydroxydopamine (6-OHDA) into the medial forebrain bundle (Galvan et al., 2001). Interestingly, despite the predominance of D2LRs in the GP, intra-pallidal injections of agonists at D2LRs had no effect (El-Banoua et al., 2004). In 6-OHDA-treated rats, grafts of fetal mesencephalic cells into the GP were shown to result in behavioral recovery (Bartlett and Mendez, 2005).

\section{SUBTHALAMIC NUCLEUS}

There is substantial dopamine loss in the STN in MPTP-treated monkeys (Pifl et al., 1990; Rommelfanger et al., 2010) and in human PD patients (Hornykiewicz, 1998) which may contribute to the expression of motor signs. In addition, unilateral 6-OHDA lesions of the rat STN may result in contralateral muscle rigidity (Flores et al., 1993).

Recent studies in rodent brain slice preparations have suggested that the reduction of dopaminergic transmission in the parkinsonian state results in a lack of activation of D2LRs and D1-receptors which, in turn, contributes to the development of irregular discharges in the STN (see section on STN above). As D5-receptors are constitutively active, even in the absence of dopamine (Tiberi and Caron, 1994; Demchyshyn et al., 2000), D5-receptor activation in the dopamine-depleted state may contribute to the development of burst discharges in the STN (Baufreton et al., 2005b), a feature of parkinsonism in monkeys (Bergman et al., 1994) and humans (Hutchison et al., 1998).

The STN may be a target for dopaminergic drug treatments. For instance, intra-STN infusions of D1LR agonists reduced the motor asymmetry in rats with ipsilateral 6-OHDA lesions of the SNc (El-Banoua et al., 2004). The contribution of D5-receptor activation to neuronal bursting in the STN has been exploited in recent experiments in which the dopamine receptor antagonist flupenthixol reduced bursting activities of STN neurons in the dopamine-depleted state, presumably through actions on constitutively active D5-receptors (Chetrit et al., 2010).

Transplantation of dopaminergic tissue or stem cells into the STN alone (Anderson and Caldwell, 2007) or in combination with striatal or nigral transplants has resulted in improved forepaw use or rotational behaviors in dopamine-depleted rats (Mukhida et al., 2001; Pavon-Fuentes et al., 2002; Inden et al., 2005), although this effect has been questioned by others (Pavon-Fuentes et al., 2002). The behavioral studies exploring the effects of injections or tissue grafts in rodents need to be replicated in monkeys before firm conclusions regarding their significance can be drawn. Because of the very small size of the rat STN, agents or cells injected in this nucleus may inadvertently diffuse to the neighboring SNr. Other than the results listed above for the STN, there is little experience with the effects of stem cells into extrastriatal regions. Given the relatively low yield of dopaminergic cells from traditional graft sources, the use of higher yield stem cell therapies aimed at replacing dopamine in extrastriatal basal ganglia regions may be a worthwhile future clinical strategy.

\section{GPi AND SNr}

While there is evidence of dopamine loss in the GPi of humans with PD (Hornykiewicz, 1998) and of MPTP-treated monkeys (Pifl et al., 1990), the behavioral consequences of this loss are not fully understood. As mentioned above, PET studies in humans have suggested that dopamine loss in the GPi may be involved in some of the early compensatory changes in PD (Whone et al., 2003).

An involvement of dopamine loss in the substantia nigra is supported by experiments exploring the effects of nigral infusions of dopamine receptor antagonists or reductions of nigral dopamine release in rats (see section on $\mathrm{SNr}$ above). These studies have suggested that actions of dopamine in the SNr may be involved in the control of normal movement and in the early compensation for striatal dopamine loss (Andersson et al., 2006). This is also suggested by behavioral experiments described earlier in this review wherein dopamine receptor activation can facilitate movement in rodents. It is unclear whether such motor effects would also occur in primates, as the primate SNr is more strongly involved in non-motor rather than motor behaviors (Parent and Hazrati, 1994; Haber and Fudge, 1997; Middleton and Strick, 2002). However, intraventricular and intranigral infusions of glial derived nerve-growth factor (GDNF) were shown to reduce parkinsonian motor deficits in MPTP-treated monkeys, associated with increased dopamine levels in the SN and the GP, but not in the striatum (Gash et al., 1996). GDNF has been clinically tested, but the therapeutic value of the explored GDNF treatment strategies, specifically the chosen delivery method and targeting, remains controversial (Gill et al., 2003; Nutt et al., 2003; Slevin et al., 2005; Lang et al., 2006). It is perhaps worth noting that the available human studies have not specifically examined (in isolation) the use of GDNF in extrastriatal tissues.

Several groups have shown that intranigral grafts of embryonic mesencephalic tissue attenuate rotational behavior and other behavioral abnormalities in 6-OHDA-treated rats (Nikkhah et al., 1995a,b; Olsson et al., 1995; Yurek, 1997; Johnston and Becker, 1999; Mukhida et al., 2001; Palmer et al., 2001) and in MPTP-treated monkeys (Starr et al., 1999; Collier et al., 2002). Furthermore, dual intrastriatal and intranigral grafts of fetal dopaminergic tissue in humans helped to improve parkinsonism in PD patients, although not with greater benefit than intrastriatal grafts (Mendez et al., 2002).

\section{EFFECTS OF CLINICALLY USED DRUG TREATMENTS AT EXTRASTRIATAL SITES}

One of the factors that determines whether clinically used dopaminergic antiparkinsonian drugs act at basal ganglia sites outside of the striatum is the availability and functional integrity of dopamine receptors at these sites in the parkinsonian state. There are, in fact, some reports of changes in the density of extrastriatal dopamine receptors in parkinsonian animals and in patients with PD. For instance, altered D1LR- and D2LR binding has been demonstrated in the STN (Flores et al., 1999; Murer et al., 1999; Mehta et al., 2000) and SN (Narang and Wamsley, 1995). Furthermore, the fraction of membrane-bound D1LRs in SNr and GPi appears to increase in 
dopamine-depleted animals (Kliem et al., 2010). In human studies, D1LR radioligand binding was decreased while the mRNA levels remained unchanged in the GPe (Hurley et al., 2001). Another study did not detect any changes in D1LR- or D2LR binding at these sites (Cortes et al., 1989).

There is little evidence that the function of D1LRs or D2LRs in the extrastriatal basal ganglia changes from the normal to the dopamine-depleted state. In our recent comparison of changes in neuronal firing rates and patterns in response to local administration of agonists at D1LRs or D2LRs in GPe, STN, GPi, and SNr, no response differences were detected between normal and parkinsonian animals (Kliem et al., 2010; unpublished observations). Taken together the extrastriatal basal ganglia could be targets for clinically used dopaminergic agonists, such as the commonly used agonists pramipexole and ropinirole. These D2LR-preferring agents may not only act in the striatum, but also at the level of the GPe or its afferents, and perhaps at glutamatergic synapses in GPi and $\mathrm{SNr}$ (see above). Activation of extrastriatal D2LRs may act to reduce the irregularity of neuronal firing (through actions in the STN) and the overall activity at the level of the basal ganglia output nuclei (through actions in $\mathrm{SNr}$ and $\mathrm{GPi}$ ).

A more detailed understanding of the effects of extrastriatal dopamine activation could also lead to a better understanding of the mechanisms involved in the frequent non-motor side effects of D2LR agonist therapies, such as disturbances in the control of impulsivity (Isaias et al., 2008), fatigue or hallucinations (Stowe et al., 2008; Truong et al., 2008). Such effects are most likely due to striatal actions of these drugs; however, extrastriatal actions may also play a role. Thus, recent studies have suggested that the STN and probably other basal ganglia areas may be part of the circuitry regulating impulsivity (Uslaner and Robinson, 2006) and reward related behaviors (Baunez et al., 2005; Joshua et al., 2009; Rouaud et al., 2010).

\section{CONCLUDING REMARKS}

It is now clear that not only the striatum, but also all of the extrastriatal basal ganglia nuclei receive dopaminergic projections. While biochemical studies have shown measurable dopamine levels in all of these nuclei, our pharmacological studies in monkeys found evidence for an endogenous tone only in GPe and GPi.

The signals carried by the dopaminergic fibers to the extrastriatal basal ganglia may overlap with those carried to the striatum, but are probably not identical with them. For instance, because the STN receives collaterals of the nigrostriatal projection, it can be expected that the dopaminergic inputs to this nucleus carry some of the same information that is also transmitted from the SNc to the striatum. In contrast, the GPi and to a much lesser extent, the GPe receives a dopaminergic projection that is separate from that terminating in the striatum so that the signals it receives may differ from those that reach the striatum. There may also be substantial heterogeneity within the nuclei themselves. Thus, in monkeys, histological studies have demonstrated dopaminergic inputs to the dorsal regions of GPe and STN, while more ventral portions of these nuclei may receive fewer (or no) dopaminergic inputs. The actual "reach" of dopamine, and the timing and strength of its effects within each of these nuclei will, of course, not only be determined by the anatomical innervation, but also by the range of diffusion. The factors influencing diffusion, in these nuclei such as the distribution and density of dopamine receptors, and the expression pattern and concentration of DAT are not sufficiently known at this time.

The large body of literature that is reviewed in this article demonstrates that virtually all of the dopamine receptor subtypes are expressed in each of the extrastriatal basal ganglia, albeit with different patterns of pre- or postsynaptic expression. With some exceptions, it appears that activation of D1LRs and D2LRs within the individual nuclei generates similar responses. For instance, our primate studies have demonstrated that activation of D1LRs in GPi and SNr leads to an inhibition of firing, most likely explained through increased GABA release in these nuclei. We also found that D2LR activation reduces neuronal activity in these nuclei, perhaps through reductions of glutamate release from STN inputs. Another example for the overall similarity of D1LR and D2LR activation would be the actions of dopamine in the STN. D1LR activation may increase the activity of STN neurons via postsynaptic effects, while D2LR activation could achieve the same effect through presynaptic inhibition of GABA release. The view that D1LR and D2LR effects are in some sense similar is obviously simplistic, but it may result in the recognition of overall response patterns of neurons in these nuclei to endogenous dopamine: the activity of GPe and STN neurons appears to be increased, while the activity of the basal ganglia output nuclei, GPi and $\mathrm{SNr}$, appears to be reduced.

As mentioned above, there is clear evidence that dopamine is lost at extrastriatal sites in $\mathrm{PD}$, and it is possible that the loss of dopamine at these sites contributes to the development of some aspects of parkinsonism. While the behavioral effects of activation or blockade of dopamine receptors at extrastriatal sites still needs to be clarified, it is clear that dopamine receptor activation in all of the nuclei discussed have strong effects on neuronal activities, even in the parkinsonian state. It seems therefore likely that these receptors mediate some of the beneficial and adverse effects of commonly used antiparkinsonian dopamine receptor agonist regimens.

In practical terms, the knowledge regarding dopaminergic effects at extrastriatal sites could be used for site-specific dopaminergic therapies in PD patients. By targeting some of the known key steps in the pathophysiology of PD, some of the well-known side effects of existing dopaminergic treatments could potentially be avoided. For instance replacement of dopamine in STN or GPe may help us to reduce neuronal bursting activities, while replacement of dopamine in GPi or $\mathrm{SNr}$ could reduce overall basal ganglia output. Given the ubiquitous presence of dopamine receptor subtypes in the striatum and extrastriatal basal ganglia, it will be challenging to devise systemic pharmacological treatments to achieve dopaminergic effects at specific basal ganglia locations. However, such specificity could be achieved by surgical procedures to reestablish dopaminergic stimulation in specific basal ganglia nuclei, through grafting, stem cell therapies, viral transfection methods, or even some of the newly developed optogenetic approaches targeting G-protein coupled receptors (Airan et al., 2009). Thus, understanding the functions of extrastriatal dopamine could not only provide a more comprehensive view of the role of dopamine in the basal ganglia, but also may prove therapeutically fruitful in the long-term. 


\section{REFERENCES}

Acosta-Garcia, J., Hernandez-Chan, N., Paz-Bermudez, F., Sierra, A., Erlij, D., Aceves, J., and Floran, B. (2009). D4 and D1 dopamine receptors modulate $[3 \mathrm{H}]$ GABA release in the substantia nigra pars reticulata of the rat. Neuropharmacology 57, 725-730.

Airan, R. D., Thompson, K. R., Fenno, L. E., Bernstein, H., and Deisseroth, K (2009). Temporally precise in vivo control of intracellular signalling. Nature 458, 1025-1029.

Alexander, G. E., Crutcher, M. D., and DeLong, M. R. (1990). Basal gangliathalamocortical circuits: parallel substrates for motor, oculomotor, 'prefrontal' and 'limbic' functions. Prog. Brain Res. 85, 119-146.

Alexander, G. E., DeLong, M. R., and Strick, P. L. (1986). Parallel organization of functionally segregated circuits linking basal ganglia and cortex. Annu. Rev. Neurosci. 9, 357-381.

Anaya-Martinez, V., Martinez-Marcos, A., Martinez-Fong, D., Aceves, J., and Erlij, D. (2006). Substantia nigra compacta neurons that innervate the reticular thalamic nucleus in the rat also project to striatum or globus pallidus: implications for abnormal motor behavior. Neuroscience 143, 477-486.

Anderson, L., and Caldwell, M. A. (2007). Human neural progenitor cell transplants into the subthalamic nucleus lead to functional recovery in a rat model of Parkinson's disease. Neurobiol. Dis. 27, 133-140.

Anderson, M. E., and Horak, F. B. (1985). Influence of the globus pallidus on arm movements in monkeys. III. Timing of movement-related information. $J$. Neurophysiol. 54, 433-448.

Andersson, D. R., Nissbrandt, H., and Bergquist, F. (2006). Partial depletion of dopamine in substantia nigra impairs motor performance without altering striatal dopamine neurotransmission. Eur. J. Neurosci. 24 617-624.

Aosaki, T., Graybiel, A. M., and Kimura, M. (1994). Effect of the nigrostriatal dopamine system on acquired neural responses in the striatum of behaving monkeys. Science 265, 412-415.

Araneda, R., and Bustos, G. (1989). Modulation of dendritic release of dopamine by $\mathrm{N}$-methyl-D-aspartate receptors in rat substantia nigra. $J$. Neurochem. 52, 962-970.

Arsenault, M. Y., Parent, A., Seguela, P., and Descarries, L. (1988). Distribution and morphological characteristics of dopamine-immunoreactive neurons in the midbrain of the squirrel monkey (Saimirisciureus). J. Comp. Neurol. 267, 489-506.
Asin, K. E., and Montana, W. E. (1988). Rotation following intranigral injections of a selective D1 or a selective D2 dopamine receptor agonist in rats. Pharmacol. Biochem. Behav. 29 89-92.

Augood, S. J., Hollingsworth, Z. R., Standaert, D. G., Emson, P. C., and Penney, J. B. Jr. (2000). Localization of dopaminergic markers in the human subthalamic nucleus. J. Comp. Neurol. 421, 247-255.

Bartlett, L. E., and Mendez, I. (2005) Dopaminergic reinnervation of the globus pallidus by fetal nigral grafts in the rodent model of Parkinson's disease. Cell Transplant. 14, 119-127.

Baufreton, J., Atherton, J. F., Surmeier, D. J., and Bevan,M.D.(2005a).Enhancement of excitatory synaptic integration by GABAergicinhibitionin the subthalamic nucleus. J. Neurosci. 25, 8505-8517.

Baufreton, J., Zhu, Z. T., Garret, M., Bioulac, B., Johnson, S. W., and Taupignon, A. I. (2005b). Dopamine receptors set the pattern of activity generated in subthalamic neurons. FASEB J. 19, 1771-1777.

Baufreton, J., and Bevan, M. D. (2008). D2-like dopamine receptor-mediated modulation of activity-dependent plasticity at GABAergic synapses in the subthalamic nucleus. J. Physiol. 586, 2121-2142.

Baufreton, J., Garret, M., Rivera, A., de la Calle, A., Gonon, F., Dufy, B., Bioulac, B., and Taupignon, A. (2003). D5 (not D1) dopamine receptors potentiate burst-firing in neurons of the subthalamic nucleus by modulating an L-type calcium conductance. $J$. Neurosci. 23, 816-825.

Baunez, C., Dias, C., Cador, M., and Amalric, M. (2005). The subthalamic nucleus exerts opposite control on cocaine and 'natural' rewards. Nat. Neurosci. 8, 484-489.

Beckstead, R. M. (1988). Association of dopamine D1 and D2 receptors with specific cellular elements in the basal ganglia of the cat: the uneven topography of dopamine receptors in the striatum is determined by intrinsic striatal cells, not nigrostriatal axons. Neuroscience 27, 851-863.

Berger, K., Przedborski, S., and Cadet, J. L. (1991). Retrograde degeneration of nigrostriatal neurons induced by intrastriatal 6-hydroxydopamine injection in rats. Brain Res. Bull. 26, 301-307.

Bergman, H., Wichmann, T., Karmon, B., and DeLong, M. R. (1994). The primate subthalamic nucleus. II. Neuronal activity in the MPTP model of parkinsonism. J. Neurophysiol. 72 507-520.
Bergquist, F., Niazi, H. S., and Nissbrandt, H. (2002). Evidence for different exocytosis pathways in dendritic and terminal dopamine release in vivo. Brain Res. 950, 245-253.

Bergquist, F., Shahabi, H. N., and Nissbrandt,H.(2003).Somatodendritic dopamine release in rat substantia nigra influences motor performance on the accelerating rod. Brain Res. 973, 81-91.

Bergson, C., Mrzljak, L., Smiley, J. F., Pappy, M., Levenson, R., and Goldman-Rakic, P. S. (1995). Regional, cellular, and subcellular variations in the distribution of D1 and D5 dopamine receptors in primate brain. J. Neurosci. 15 7821-7836.

Bergstrom, D. A., and Walters, J. R. (1984). Dopamine attenuates the effects of GABA on single unit activity in the globus pallidus. Brain Res. 310, 23-33.

Bernardini, G. L., Gu, X., Viscardi, E., and German, D. C. (1991). Amphetamine-induced and spontaneous release of dopamine from A9 and A10 cell dendrites: an in vitro electrophysiological study in the mouse. J. Neural Transm. Gen. Sect 84, 183-193.

Besson, M. J., Graybiel,A. M., and Nastuk M.A.(1988). [3H]SCH 23390 binding to $\mathrm{D} 1$ dopamine receptors in the basal ganglia of the cat and primate: delineation of striosomal compartments and pallidal and nigral subdivisions. Neuroscience 26, 101-119.

Beurrier, C., Congar, P., Bioulac, B., and Hammond, C. (1999). Subthalamic nucleus neurons switch from singlespike activity to burst-firing mode. $J$. Neurosci. 19, 599-609.

Bevan, M. D., Magill, P. J., Terman, D. Bolam, J. P., and Wilson, C. J. (2002). Move to the rhythm: oscillations in the subthalamic nucleus-external globus pallidus network. Trends Neurosci. 25 525-531.

Billings, L. M., and Marshall, J. F. (2003) D2 antagonist-induced c-fos in an identified subpopulation of globus pallidus neurons by a direct intrapallidal action. Brain Res. 964 237-243.

Bjorklund, A., and Lindvall, O. (1975) Dopamine in dendrites of substantia nigra neurons - suggestions for a role in dendritic terminals. Brain Res. 83 , 531-537.

Blakely, R. D., and Bauman, A. L. (2000) Biogenic amine transporters: regulation in flux. Curr. Opin. Neurobiol. 10 328-336.

Bouthenet, M. L., Martres, M. P., Sales, N., and Schwartz, J. C. (1987). A detailed mapping of dopamine D-2 receptors in rat central nervous system by autoradiography with [125I]iodosulpride. Neuroscience 20, 117-155.

Boyson, S. J., McGonigle, P., and Molinoff, P. B. (1986). Quantitative autoradiographic localization of the D1 and D2 subtypes of dopamine receptors in rat brain. J. Neurosci. 6, 3177-3188.

Caille, I., Dumartin, B., and Bloch, B (1996). Ultrastructural localization of D1 dopamine receptor immunoreactivity in rat striatonigral neurons and its relation with dopaminergic innervation. Brain Res. 730, 17-31.

Calabresi, P., Centonze, D., Gubellini, P., Marfia, G. A., Pisani, A., Sancesario, G., and Bernardi, G. (2000). Synaptic transmission in the striatum: from plasticity to neurodegeneration. Prog. Neurobiol. 61, 231-265.

Calabresi, P., Picconi, B., Tozzi, A., and Di Filippo, M. (2007). Dopaminemediated regulation of corticostriatal synaptic plasticity. Trends Neurosci. 30, 211-219.

Campbell, G. A., Eckardt, M. J., and Weight, F. F. (1985). Dopaminergic mechanisms in subthalamic nucleus of rat: analysis using horseradish peroxidase and microiontophoresis. Brain Res. 333, 261-270.

Cenci, M. A., and Lundblad, M. (2006). Post- versus presynaptic plasticity in L-DOPA-induced dyskinesia. J. Neurochem. 99, 381-392.

Chang, H. T., Wilson, C. J., and Kitai, S. T. (1981). Single neostriatal efferent axons in the globus pallidus: a light and electron microscopic study. Science 213, 915-918.

Chetrit, J., Taupignon, A., Morin, S., Bouali-Benazzouz, R., Bioulac, B., Gross, C., and Benazzouz, A. (2010). Constitutive activity of dopamine D5 receptors located in the subthalamic nucleus is a potential target for the treatment of Parkinson's disease. Int Basal Ganglia Soc. Abstr. P-190.

Ciliax, B. J., Drash, G. W., Staley, J. K., Haber, S., Mobley, C. J., Miller, G. W., Mufson, E. J., Mash, D. C., and Levey, A. I. (1999). Immunocytochemical localization of the dopamine transporter in human brain. J. Comp. Neurol. 409, 38-56.

Ciliax, B. J., Heilman, C., Demchyshyn, L. L., Pristupa, Z. B., Ince, E., Hersch, S. M., Niznik, H. B., and Levey, A. I. (1995). The dopamine transporter: immunochemical characterization and localization in brain. J. Neurosci. $15,1714-1723$

Ciliax, B. J., Nash, N., Heilman, C., Sunahara, R., Hartney, A., Tiberi, M., Rye, D. B., Caron, M. G., Niznik, H. B., and Levey, A. I. (2000). Dopamine $\mathrm{D}(5)$ receptor immunolocalization in rat and monkey brain. Synapse 37, 125-145. 
Clark, D., and White, F. J. (1987). D1 dopamine receptor - the search for a function: a critical evaluation of the D1/D2 dopamine receptor classification and its functional implications. Synapse 1, 347-388.

Collier, T. J., Sortwell, C. E., Elsworth, J. D., Taylor, J. R., Roth, R. H., Sladek, J. R. Jr., and Redmond, D. E., Jr. (2002). Embryonic ventral mesencephalic grafts to the substantia nigra of MPTP-treated monkeys: feasibility relevant to multiple-target grafting as a therapy for Parkinson's disease. J. Comp. Neurol. 442, 320-330.

Cooper, A. J., and Stanford, I. M. (2001). Dopamine D2 receptor mediated presynaptic inhibition of striatopallidal GABA(A) IPSCs in vitro. Neuropharmacology 41, 62-71.

Cortes, R., Camps, M., Gueye, B., Probst,A., and Palacios, J. M. (1989). Dopamine receptors in human brain: autoradiographic distribution of D1 and D2 sites in Parkinson syndrome of different etiology. Brain Res. 483, 30-38.

Cossette, M., Levesque, M., and Parent, A. (1999). Extrastriatal dopaminergic innervation of human basal ganglia. Neurosci. Res. 34, 51-54.

Costall, B., Naylor, R. J., and Olley, J. E. (1972a). Catalepsy and circling behaviour after intracerebral injections of neuroleptic, cholinergic and anticholinergic agents into the caudate-putamen, globus pallidus and substantia nigra of rat brain. Neuropharmacology 11, 645-663.

Costall, B., Naylor, R. J., and Olley, J. E. (1972b). Stereotypic and anticataleptic activities of amphetamine after intracerebral injections. Eur. J. Pharmacol. 18, 83-94.

Coulter, C. L., Happe, H. K., Bergman, D. A., and Murrin, L. C. (1995). Localization and quantification of the dopamine transporter: comparison of [3H]WIN 35,428 and [125I]RTI-55. Brain Res. 690, 217-224.

Cragg, S., Rice, M. E., and Greenfield, S. A. (1997). Heterogeneity of electrically evoked dopamine release and reuptake in substantia nigra, ventral tegmental area, and striatum. J. Neurophysiol. 77, 863-873.

Cragg, S. J. (2003). Variable dopamine release probability and short-term plasticity between functional domains of the primate striatum. J. Neurosci. 23, 4378-4385.

Cragg, S. J., Baufreton, J., Xue, Y., Bolam, J. P., and Bevan, M. D. (2004). Synaptic release of dopamine in the subthalamic nucleus. Eur. J. Neurosci. 20, 1788-1802.

Cragg, S. J., and Greenfield, S. A. (1997). Differential autoreceptor control of somatodendritic and axon terminal dopamine release in substantia nigra, ventral tegmental area, and striatum. J. Neurosci. 17, 5738-5746.

Cragg, S. J., Nicholson, C., Kume-Kick, J., Tao, L., and Rice, M. E. (2001). Dopamine-mediated volume transmission in midbrain is regulated by distinct extracellular geometry and uptake. J. Neurophysiol. 85, 1761-1771.

Crocker, A. D. (1995). A new view of the role of dopamine receptors in the regulation of muscle tone. Clin. Exp. Pharmacol. Physiol. 22, 846-850.

Dawson, T. M., Barone, P., Sidhu, A., Wamsley, J.K., and Chase, T.N. (1988). The D1 dopamine receptor in the rat brain: quantitative autoradiographic localization using an iodinated ligand. Neuroscience 26, 83-100.

Dawson, T. M., Gehlert, D. R., McCabe, R. T., Barnett, A., and Wamsley, J. K. (1986). D-1 dopamine receptors in the rat brain: a quantitative autoradiographic analysis. J. Neurosci. 6, 2352-2365.

Day, M., Wang, Z., Ding, J., An, X., Ingham, C.A., Shering, A. F., Wokosin, D., Ilijic, E., Sun, Z., Sampson, A. R., Mugnaini, E., Deutch, A.Y., Sesack, S. R., Arbuthnott, G. W., and Surmeier, D. J. (2006). Selective elimination of glutamatergic synapses on striatopallidal neurons in Parkinson disease models. Nat. Neurosci. 9, 251-259.

DeLong, M. R. (1971). Activity of pallidal neurons during movement. $J$. Neurophysiol. 34, 414-427.

Demchyshyn, L. L., McConkey, F., and Niznik, H. B. (2000). Dopamine D5 receptor agonist high affinity and constitutive activity profile conferred by carboxyl-terminal tail sequence. $J$. Biol. Chem. 275, 23446-23455.

Deng, Y. P., Lei, W. L., and Reiner, A. (2006). Differential perikaryal localization in rats of D1 and D2 dopamine receptors on striatal projection neuron types identified by retrograde labeling. J. Chem. Neuroanat. 32, 101-116.

Dewar, D., Jenner, P., and Marsden, C. D. (1987). Effects of opioid agonist drugs on the in vitro release of $3 \mathrm{H}-\mathrm{GABA}$, $3 \mathrm{H}$-dopamine and $3 \mathrm{H}-5 \mathrm{HT}$ from slices of rat globus pallidus. Biochem. Pharmacol. 36, 1738-1741.

El-Banoua, F., Caraballo, I., Flores, J. A., Galan-Rodriguez, B., and FernandezEspejo, E. (2004). Effects on turning of microinjections into basal ganglia of $\mathrm{D}(1)$ and $\mathrm{D}(2)$ dopamine receptors agonists and the cannabinoid CB(1) antagonist SR141716A in a rat Parkinson's model. Neurobiol. Dis. 16, 377-385.

Elverfors, A., Pileblad, E., Lagerkvist, S., Bergquist, F., Jonason, J., and
Nissbrandt, H. (1997). 3-Methoxytyramine formation following monoamine oxidase inhibition is a poor index of dendritic dopamine release in the substantia nigra. $J$. Neurochem. 69, 1684-1692.

Fallon, J. H., and Moore, R. Y. (1978). Catecholamine innervation of the basal forebrain. IV. Topography of the dopamine projection to the basal forebrain and neostriatum. J. Comp. Neurol. 180, 545-580.

Ferre, S., O'Connor, W. T., Svenningsson, P., Bjorklund, L., Lindberg, J., Tinner, B., Stromberg, I., Goldstein, M., Ogren, S. O., Ungerstedt, U., Fredholm, B B., and Fuxe, K. (1996). Dopamine D1 receptor-mediated facilitation of GABAergic neurotransmission in the rat strioentopenduncular pathway and its modulation by adenosine Al receptor-mediated mechanisms. Eur. J. Neurosci. 8, 1545-1553.

Filion, M., and Tremblay, L. (1991) Abnormal spontaneous activity of globus pallidus neurons in monkeys with MPTP-induced parkinsonism. Brain Res. 547, 142-151.

Flajolet, M., Wang, Z., Futter, M., Shen, W., Nuangchamnong, N., Bendor, J., Wallach, I., Nairn, A. C., Surmeier, D. J., and Greengard, P. (2008). FGF acts as a co-transmitter through adenosine $\mathrm{A}(2 \mathrm{~A})$ receptor to regulate synaptic plasticity. Nat. Neurosci. 11, 1402-1409.

Floran, B., Aceves, J., Sierra, A., and Martinez-Fong, D. (1990). Activation of D1 dopamine receptors stimulates the release of GABA in the basal ganglia of the rat. Neurosci. Lett. 116 136-140.

Floran, B., Floran, L., Erlij, D., and Aceves, J. (2004). Dopamine D4 receptors inhibit depolarization-induced $[3 \mathrm{H}]$ GABA release in the rat subthalamic nucleus. Eur. J. Pharmacol. 498, 97-102.

Floran, B., Floran, L., Sierra,A., and Aceves, J. (1997). D2 receptor-mediated inhibition of GABA release by endogenous dopamine in the rat globus pallidus. Neurosci. Lett. 237, 1-4.

Flores, G., Liang, J. J., Sierra, A., MartinezFong, D., Quirion, R., Aceves, J., and Srivastava, L. K. (1999). Expression of dopamine receptors in the subthalamic nucleus of the rat: characterization using reverse transcriptase-polymerase chain reaction and autoradiography. Neuroscience 91, 549-556.

Flores, G., Valencia, J., Rosales, M. G., Sierra, A., and Aceves, J. (1993). Appearance of EMG activity and motor asymmetry after unilateral lesions of the dopaminergic innervation to the subthalamic nucleus in the rat. Neurosci. Lett. 162, 153-156.
Ford, C. P., Gantz, S. C., Phillips, P. E., and Williams, J. T. (2010). Control of extracellular dopamine at dendrite and axon terminals. J. Neurosci. 30, 6975-6983.

Francois, C., Savy, C., Jan, C., Tande, D., Hirsch, E. C., and Yelnik, J. (2000). Dopaminergic innervation of the subthalamic nucleus in the normal state, in MPTP-treated monkeys, and in Parkinson's disease patients. J. Comp. Neurol. 425, 121-129.

Fremeau, R. T. Jr., Duncan, G. E., Fornaretto, M.G., Dearry, A., Gingrich, J. A., Breese, G. R., and Caron, M. G. (1991). Localization of D1 dopamine receptor mRNA in brain supports a role in cognitive, affective, and neuroendocrine aspects of dopaminergic neurotransmission. Proc. Natl. Acad. Sci. U.S.A. 88, 3772-3776.

Fuchs, H., and Hauber, W. (2004). Dopaminergic innervation of the rat globus pallidus characterized by microdialysis and immunohistochemistry. Exp. Brain Res. 154, 66-75.

Galvan, A., Floran, B., Erlii, D., and Aceves, J. (2001). Intrapallidal dopamine restores motor deficits induced by 6-hydroxydopamine in the rat. $J$. Neural Transm. 108, 153-166.

Galvan, A., and Wichmann, T. (2008). Pathophysiology of parkinsonism. Clin. Neurophysiol. 119, 1459-1474.

Garraux, G., Peigneux, P., Carson, R. E., and Hallett, M. (2007). Task-related interaction between basal ganglia and cortical dopamine release. J. Neurosci. 27, 14434-14441.

Gash, D. M., Zhang, Z., Ovadia, A., Cass, W. A., Yi, A., Simmerman, L., Russell, D., Martin, D., Lapchak, P. A., Collins, F., Hoffer, B. J., and Gerhardt, G. A. (1996). Functional recovery in parkinsonian monkeys treated with GDNF. Nature 380, 252-255.

Gauthier, J., Parent, M., Levesque, M., and Parent,A. (1999). The axonal arborization of single nigrostriatal neurons in rats. Brain Res. 834, 228-232.

Gerfen, C. R. (1995). Dopamine receptor function in the basal ganglia. Clin. Neuropharmacol. 18, S162-S177.

Gerfen, C. R., Engber, T. M., Mahan, L. C., Susel, Z., Chase, T. N., Monsma, F. J. Jr., and Sibley, D. R. (1990). D1 and D2 dopamine receptor-regulated gene expression of striatonigral and striatopallidal neurons. Science 250 , 1429-1432.

Gerhardt, G. A., Cass, W. A., Yi, A., Zhang, Z., and Gash, D. M. (2002). Changes in somatodendritic but not terminal dopamine regulation in aged rhesus monkeys. J. Neurochem. 80, 168-177.

Gill, S. S., Patel, N. K., Hotton, G. R., O'Sullivan, K., McCarter, R., Bunnage, M., Brooks, D. J., Svendsen, C. N., and 
Heywood, P. (2003). Direct brain infusion of glial cell line-derived neurotrophic factor in Parkinson disease. Nat. Med. 9, 589-595.

Gleason, S. D., and Witkin, J. M. (2004). Effects of dopamine D1 receptor full agonists in rats trained to discriminate SKF 38393. Behav Pharmacol $15,85-89$.

Gnanalingham, K. K., Milkowski, N. A., Smith, L. A., Hunter, A. J., Jenner, P., and Marsden, C. D. (1995). Shortand long-term changes in striatal and extrastriatal dopamine uptake sites in the MPTP-treated common marmoset. Eur. J. Pharmacol. 277, 235-241.

Groves, P. M., and Linder, J. C. (1983). Dendro-dendritic synapses in substantia nigra: descriptions based on analysis of serial sections. Exp. Brain Res. 49, 209-217.

Gurevich, E. V., and Joyce, J. N. (1999). Distribution of dopamine D3 receptor expressing neurons in the human forebrain: comparison with D2 receptor expressing neurons. Neuropsychopharmacology 20, 60-80.

Haber, S. N., and Fudge, J. L. (1997). The primate substantia nigra and VTA: integrative circuitry and function. Crit. Rev. Neurobiol. 11,323-342.

Haber, S. N., Kunishio, K., Mizobuchi, M., and Lynd-Balta, E. (1995). The orbital and medial prefrontal circuit through the primate basal ganglia. J. Neurosci. $15,4851-4867$.

Hadipour Niktarash, A., Lee, H., Khan, Z. U., Smith, Y., and Wichmann, T. (2008). Effects of D2-like dopamine receptor activation on neuronal activity in substantia nigra pars reticulata and globus pallidus in monkeys. Soc. Neurosci. Abstr. 274.271.

Hassani, O. K., and Feger, J. (1999). Effects of intrasubthalamic injection of dopamine receptor agonists on subthalamic neurons in normal and 6-hydroxydopamine-lesioned rats: an electrophysiological and c-Fos study. Neuroscience 92, 533-543.

Hassani, O. K., Francois, C., Yelnik, J., and Feger, J. (1997). Evidence for a dopaminergic innervation of the subthalamic nucleus in the rat. Brain Res. 749, 88-94.

Hauber, W. (1998). Blockade of subthalamic dopamine D1 receptors elicits akinesia in rats. Neuroreport 9 , 4115-4118.

Hauber, W., and Fuchs, H. (2000). Dopamine release in the rat globus pallidus characterised by in vivo microdialysis. Behav. Brain Res. 111, 39-44.

Hauber, W., and Lutz, S. (1999). Dopamine D1 or D2 receptor blockade in the globus pallidus produces akinesia in the rat. Behav. Brain Res. $106,143-150$.

Hausser, M., Stuart, G., Racca, C., and Sakmann, B. (1995). Axonal initiation and active dendritic propagation of action potentials in substantia nigra neurons. Neuron 15 , 637-647.

Hazrati, L. N., and Parent, A. (1992). Convergence of subthalamic and striatal efferents at pallidal level in primates: an anterograde double-labeling study with biocytin and PHA-L. Brain Res. 569, 336-340.

Hedreen, J. C. (1999). Tyrosine hydroxylase-immunoreactive elements in the human globus pallidus and subthalamic nucleus. J. Comp. Neurol. 409, 400-410.

Heintz, N. (2001). BAC to the future: the use of bac transgenic mice for neuroscience research. Nat. Rev. Neurosci. 2, 861-870.

Hemsley, K. M., and Crocker, A. D. (1998). The effects of an irreversible dopamine receptor antagonist, N-ethoxycarbonyl-2-ethoxy-1,2dihydroquinoline (EEDQ), on the regulation of muscle tone in the rat: the role of the substantia nigra. Neurosci. Lett. 251, 77-80.

Hemsley, K. M., and Crocker, A. D. (2001). Changes in muscle tone are regulated by $\mathrm{D} 1$ and $\mathrm{D} 2$ dopamine receptors in the ventral striatum and D1 receptors in the substantia nigra. Neuropsychopharmacology 25, 514-526.

Hernandez, A., Ibanez-Sandoval, O., Sierra, A., Valdiosera, R., Tapia, D., Anaya, V., Galarraga, E., Bargas, J., and Aceves, J. (2006). Control of the subthalamic innervation of the rat globus pallidus by D2/3 and D4 dopamine receptors. J. Neurophysiol. 96, 2877-2888.

Hernandez, A., Sierra, A., Valdiosera, R., Floran, B., Erlij, D., and Aceves, J. (2007). Presynaptic D1 dopamine receptors facilitate glutamatergic neurotransmission in the rat globus pallidus. Neurosci. Lett. 425, 188-191.

Hoffman, A. F., and Gerhardt, G. A. (1999). Differences in pharmacological properties of dopamine release between the substantia nigra and striatum: an in vivo electrochemical study. J. Pharmacol. Exp. Ther. 289, 455-463.

Hoover, B. R., and Marshall, J. F. (2004). Molecular, chemical, and anatomical characterization of globus pallidus dopamine D2 receptor mRNAcontaining neurons. Synapse 52, 100-113.

Hoover, J. E., and Strick, P. L. (1993). Multiple output channels in the basal ganglia. Science 259, 819-821.
Hornykiewicz, O. (1998). Biochemical aspects of Parkinson's disease. Neurology 51, S2-S9.

Hurd, Y. L., Suzuki, M., and Sedvall, G. C. (2001). D1 and D2 dopamine receptor mRNA expression in whole hemisphere sections of the human brain. $J$. Chem. Neuroanat. 22, 127-137.

Hurley, M. J., Mash, D. C., and Jenner, P. (2001). Dopamine D(1) receptor expression in human basal ganglia and changes in Parkinson's disease. Brain Res. Mol. Brain Res. 87, 271-279.

Hutchinson, W. D., Levy, R., Dostrovsky, J. O., Lozano, A. M., and Lang, A. E. (1997). Effects of apomorphine on globus pallidus neurons in parkinsonian patients. Ann. Neurol. 42, 767-775.

Hutchison, W. D., Allan, R. J., Opitz, H., Levy, R., Dostrovsky, J. O., Lang, A. E., and Lozano, A. M. (1998). Neurophysiological identification of the subthalamic nucleus in surgery for Parkinson's disease. Ann. Neurol. $44,622-628$.

Ibanez-Sandoval, O., Hernandez, A., Floran, B., Galarraga, E., Tapia, D., Valdiosera, R., Erlij, D., Aceves, J., and Bargas, J. (2006). Control of the subthalamic innervation of substantia nigra pars reticulata by D1 and D2 dopamine receptors. J. Neurophysiol. 95, 1800-1811.

Inden, M., Kim, D. H., Qi, M., Kitamura, Y., Yanagisawa, D., Nishimura, K., Tsuchiya, D., Takata, K., Hayashi, K., Taniguchi, T., Yoshimoto, K., Shimohama, S., Sumi, S., and Inoue, K. (2005). Transplantation of mouse embryonic stem cell-derived neurons into the striatum, subthalamic nucleus and substantia nigra, and behavioral recovery in hemiparkinsonian rats. Neurosci. Lett. 387, 151-156.

Isaias, I. U., Siri, C., Cilia, R., De Gaspari, D., Pezzoli, G., and Antonini, A. (2008). The relationship between impulsivity and impulse control disorders in Parkinson's disease. Mov. Disord. 23, 411-415.

Jackson, E. A., and Kelly, P. H. (1983a), Nigral dopaminergic mechanisms in drug-induced circling. Brain Res. Bull. $11,605-611$.

Jackson, E. A., and Kelly, P. H. (1983b) Role of nigral dopamine in amphetamine-induced locomotor activity. Brain Res. 278, 366-369.

Jan, C., Francois, C., Tande, D., Yelnik, J., Tremblay, L., Agid, Y., and Hirsch, E. (2000). Dopaminergic innervation of the pallidum in the normal state, in MPTP-treated monkeys and in parkinsonian patients. Eur. J. Neurosci. 12, 4525-4535.

Johnson, A. E., Coirini, H., Kallstrom, L., and Wiesel, F. A. (1994).
Characterization of dopamine receptor binding sites in the subthalamic nucleus. Neuroreport 5, 1836-1838.

Johnson, S. W. (2008). Rebound bursts following inhibition: how dopamine modifies firing pattern in subthalamic neurons. J. Physiol. 586, 2033.

Johnston, R. E., and Becker, J. B. (1999). Behavioral changes associated with grafts of embryonic ventral mesencephalon tissue into the striatum and/ or substantia nigra in a rat model of Parkinson's disease. Behav. Brain Res. 104, 179-187.

Joshua, M., Adler, A., Rosin, B., Vaadia, E., and Bergman, H. (2009). Encoding of probabilistic rewarding and aversive events by pallidal and nigral neurons. J. Neurophysiol. 101, 758-772.

Kaneda, K., Nambu, A., Tokuno, H., and Takada, M. (2002). Differential processing patterns of motor information via striatopallidal and striatonigral projections. J. Neurophysiol. 88, 1420-1432.

Kass, J. I., and Mintz, I. M. (2006). Silent plateau potentials, rhythmic bursts, and pacemaker firing: three patterns of activity that coexist in quadristable subthalamic neurons. Proc. Natl. Acad. Sci. U.S.A. 103, 183-188.

Kelly, E., Jenner, P., and Marsden, C. D. (1987). Comparison of changes in locomotor activity with striatal homovanillic acid and 3,4-dihydroxyphenylacetic acid concentrations following the bilateral intranigral injection of dopamine agonist drugs in rats. J. Pharm. Pharmacol. 39, 196-202.

Kelly, R. M., and Strick, P. L. (2004). Macro-architecture of basal ganglia loops with the cerebral cortex: use of rabies virus to reveal multisynaptic circuits. Prog. Brain Res. 143, 449-459.

Khan, Z. U., Gutierrez, A., Martin, R., Penafiel, A., Rivera, A., and De La Calle, A. (1998). Differential regional and cellular distribution of dopamine D2-like receptors: an immunocytochemical study of subtype-specific antibodies in rat and human brain. $J$. Comp. Neurol. 402, 353-371.

Khan, Z. U., Gutierrez, A., Martin, R., Penafiel, A., Rivera, A., and de la Calle, A. (2000). Dopamine D5 receptors of rat and human brain. Neuroscience 100, 689-699.

Kita, H., and Kitai, S. T. (1987). Efferent projections of the subthalamic nucleus in the rat: light and electron microscopic analysis with the PHA-L method. J. Comp. Neurol. 260, 435-452.

Kita, H., Nambu, A., Kaneda, K. Tachibana, Y., and Takada, M. (2004). Role of ionotropic glutamatergic and GABAergic inputs on the firing activity 
of neurons in the external pallidum in awake monkeys. J. Neurophysiol. 92, 3069-3084.

Kliem, M. A., Maidment, N. T., Ackerson, L. C., Chen, S., Smith, Y., and Wichmann, T. (2007a). Activation of nigral and pallidal dopamine D1-like receptors modulates basal ganglia outflow in monkeys. J. Neurophysiol. 89, 1489-1500.

Kliem, M. A., Pare, J. F., Khan, Z. U., Wichmann, T., and Smith, Y. (2007b). Comparative ultrastructural analysis of D1 and D5 dopamine receptor distribution in the substantia nigra and globus pallidus of monkeys. Int. Basal Ganglia Soc. Abstr. 72.

Kliem, M. A., Pare, J. F., Khan, Z. U., Wichmann, T., and Smith, Y. (2010). Ultrastructural localization and function of dopamine D1-like receptors in the substantia nigra pars reticulata and the internal segment of the globus pallidus of parkinsonian monkeys. Eur. J. Neurosci. 31, 836-851.

Koeltzow, T. E., Xu, M., Cooper, D. C., Hu, X. T., Tonegawa, S., Wolf, M. E., and White, F. J. (1998). Alterations in dopamine release but not dopamine autoreceptor function in dopamine D3 receptor mutant mice. J. Neurosci. 18, 2231-2238.

Korf, J., Zieleman, M., and Westerink, B. H. (1976). Dopamine release in substantia nigra? Nature 260, 257-258.

Koshikawa, N., Koshikawa, F., Tomiyama, K., Kikuchi de Beltran, K., Kamimura, F., and Kobayashi, M. (1990). Effects of dopamine D1 and D2 agonists and antagonists injected into the nucleus accumbens and globus pallidus on jaw movements of rats. Eur. J. Pharmacol. 182, 375-380.

Kreiss, D. S., Anderson, L. A., and Walters, J. R. (1996). Apomorphine and dopamine $\mathrm{D}(1)$ receptor agonists increase the firing rates of subthalamic nucleus neurons. Neuroscience 72, 863-876.

Kreitzer,A. C., and Malenka, R. C. (2007). Endocannabinoid-mediated rescue of striatal LTD and motor deficits in Parkinson's disease models. Nature 445, 643-647.

Kreitzer,A. C., and Malenka, R. C. (2008). Striatal plasticity and basal ganglia circuit function. Neuron 60, 543-554.

Kuhr, W. G., Bigelow, J. C., and Wightman, R. M. (1986). In vivo comparison of the regulation of releasable dopamine in the caudate nucleus and the nucleus accumbens of the rat brain. J. Neurosci. 6, 974-982.

Lacey, M. G., Mercuri, N. B., and North, R. A. (1987). Dopamine acts on D2 receptors to increase potassium conductance in neurones of the rat substantia nigra zona compacta. J. Physiol. 392, 397-416.
Lanciego, J. L., Gonzalo, N., Castle, M., Sanchez-Escobar, C., Aymerich, M. S., and Obeso, J. A. (2004). Thalamic innervation of striatal and subthalamic neurons projecting to the rat entopeduncular nucleus. Eur. J. Neurosci. 19, 1267-1277.

Lang, A. E., Gill, S., Patel, N. K., Lozano, A., Nutt, J. G., Penn, R., Brooks, D. J., Hotton, G., Moro, E., Heywood, P., Brodsky, M. A., Burchiel, K., Kelly, P., Dalvi, A., Scott, B., Stacy, M., Turner, D., Wooten, V. G., Elias, W. J., Laws, E. R., Dhawan, V., Stoessl, A. J., Matcham, J., Coffey, R. J., and Traub, M. (2006). Randomized controlled trial of intraputamenal glial cell linederived neurotrophic factor infusion in Parkinson disease. Ann. Neurol. 59, 459-466.

Lavoie, B., Smith, Y., and Parent, A. (1989). Dopaminergic innervation of the basal ganglia in the squirrel monkey as revealed by tyrosine hydroxylase immunohistochemistry. J. Comp. Neurol. 289, 36-52.

Lee, C. Y., Double, K. L., and Crocker, A. D. (1995). Expression of stereotyped behaviour requires stimulation of nigral D1 dopamine receptors. Brain Res. 681, 205-208.

Leenders, K. L., Salmon, E. P., Tyrrell, P., Perani, D., Brooks, D. J., Sager, H., Jones, T., Marsden, C. D., and Frackowiak, R. S. (1990). The nigrostriatal dopaminergic system assessed in vivo by positron emission tomography in healthy volunteer subjects and patients with Parkinson's disease. Arch. Neurol. 47, 1290-1298.

Letchworth, S. R., Nader, M. A., Smith, H. R., Friedman, D. P., and Porrino, L. J. (2001). Progression of changes in dopamine transporter binding site density as a result of cocaine selfadministration in rhesus monkeys. $J$. Neurosci. 21, 2799-2807.

Levey, A. I., Hersch, S. M., Rye, D. B., Sunahara, R. K., Niznik, H. B., Kitt, C. A., Price, D. L., Maggio, R., Brann, M. R., and Ciliax, B. J. (1993). Localization of D1 and D2 dopamine receptors in brain with subtype-specific antibodies. Proc. Natl. Acad. Sci. U.S.A. 90, 8861-8865.

Leviel, V., Cheramy, A., and Glowinski, J. (1979). Role of the dendritic release of dopamine in the reciprocal control of the two nigro-striatal dopaminergic pathways. Nature 280, 236-239.

Lindvall, O., and Bjorklund, A. (1979). Dopaminergic innervation of the globus pallidus by collaterals from the nigrostriatal pathway. Brain Res. 172, 169-173.

Mallet, L., Schupbach, M., N’Diaye, K., Remy, P., Bardinet, E., Czernecki, V., Welter, M. L., Pelissolo, A., Ruberg, M., Agid, Y., and Yelnik, J. (2007).
Stimulation of subterritories of the subthalamic nucleus reveals its role in the integration of the emotional and motor aspects of behavior. Proc. Natl. Acad. Sci. U.S.A. 104, 10661-10666.

Mansour, A., Meador-Woodruff, J. H., Zhou, Q., Civelli, O., Akil, H., and Watson, S. J. (1992). A comparison of D1 receptor binding and $m R N A$ in rat brain using receptor autoradiographic and in situ hybridization techniques. Neuroscience 46, 959-971.

Marcusson, J., and Eriksson, K. (1988). [H-3] Gbr-12935 binding to dopamine uptake sites in the human-brain. Brain Res. 457, 122-129.

Marshall, J. F., Henry, B. L., Billings, L. M., and Hoover, B. R. (2001). The role of the globus pallidus D2 subfamily of dopamine receptors in pallidal immediate early gene expression. Neuroscience 105, 365-378.

Martin, L. P., and Waszczak, B. L. (1994) D-1 agonist-induced excitation of substantia-nigra pars reticulata neurons - mediation by $\mathrm{D}-1$ receptors on striatonigral terminals via a pertussistoxin-sensitive coupling pathway. $J$. Neurosci. 14, 4494-4506.

Martin, L. P., and Waszczak, B. L. (1996) Dopamine D2, receptor-mediated modulation of the GABAergic inhibition of substantia nigra pars reticulata neurons. Brain Res. 729, 156-169.

Matsumura, M., Tremblay, L., Richard, H., and Filion, M. (1995). Activity of pallidal neurons in the monkey during dyskinesia induced by injection of bicuculline in the external pallidum. Neuroscience 65, 59-70.

Matuszewich, L., and Yamamoto, B. K. (1999). Modulation of GABA release by dopamine in the substantia nigra. Synapse 32, 29-36.

Mehta, A., Thermos, K., and Chesselet, M. F. (2000). Increased behavioral response to dopaminergic stimulation of the subthalamic nucleus after nigrostriatal lesions. Synapse 37, 298-307.

Meloni, E. G., and Davis, M. (2004). The substantia nigra pars reticulata mediates the enhancement of startle by the dopamine D1 receptor agonist SKF 82958 in rats. Psychopharmacology (Berl.) 174, 228-236.

Mendez, I., Dagher, A., Hong, M., Gaudet, P., Weerasinghe, S., McAlister, V., King, D., Desrosiers, J., Darvesh, S. Acorn, T., and Robertson, H. (2002). Simultaneous intrastriatal and intranigral fetal dopaminergic grafts in patients with Parkinson disease: a pilot study. Report of three cases. J. Neurosurg. 96, 589-596.

Mercuri, N. B., Saiardi, A., Bonci, A., Picetti, R., Calabresi, P., Bernardi, G., and Borrelli, E. (1997). Loss of autoreceptor function in dopaminergic neurons from dopamine D2 receptor deficient mice. Neuroscience 79, 323-327.

Middleton, F. A., and Strick, P. L. (1997). New concepts about the organization of basal ganglia output. Adv. Neurol. 74, 57-68.

Middleton, F. A., and Strick, P. L. (2002). Basal-ganglia 'projections' to the prefrontal cortex of the primate. Cereb. Cortex 12, 926-935.

Miller, W. C., and DeLong, M. R. (1987). "Altered tonic activity of neurons in the globus pallidus and subthalamic nucleus in the primate MPTP model of parkinsonism," in The Basal Ganglia II, eds M. B. Carpenter and A. Jayaraman (New York: Plenum Press), 415-427.

Mink, J. W. (1996). The basal ganglia: focused selection and inhibition of competing motor programs. Prog. Neurobiol. 50, 381-425.

Mintz, I., Hammond, C., and Feger, J. (1986). Excitatory effect of iontophoretically applied dopamine on identified neurons of the rat subthalamic nucleus. Brain Res. 375, 172-175.

Missale, C., Castelletti, L., Govoni, S., Spano, P. F., Trabucchi, M., and Hanbauer, I. (1985). Dopamine uptake is differentially regulated in rat striatum and nucleus accumbens. J. Neurochem. 45, 51-56.

Missale, C., Nash, S. R., Robinson, S. W., Jaber, M., and Caron, M. G. (1998) Dopamine receptors: from structure to function. Physiol. Rev. 78, 189-225.

Miyazaki, T., and Lacey, M. G. (1998). Presynaptic inhibition by dopamine of a discrete component of GABA release in rat substantia nigra pars reticulata. J. Physiol. 513 (Pt 3), 805-817.

Moriizumi, T., Leduc-Cross, B., Wu, J. Y., and Hattori, T. (1992). Separate neuronal populations of the rat substantia nigra pars lateralis with distinct projection sites and transmitter phenotypes. Neuroscience 46, 711-720.

Mouroux, M., Hassani, O. K., and Feger, J. (1997). Electrophysiological and Fos immunohistochemical evidence for the excitatory nature of the parafascicular projection to the globus pallidus. Neuroscience 81, 387-397.

Mrzljak, L., Bergson, C., Pappy, M., Huff, R., Levenson, R., and Goldman-Rakic, P.S. (1996). Localization of dopamine D4 receptors in GABAergic neurons of the primate brain. Nature 381, 245-248.

Mukhida, K., Baker, K. A., Sadi, D., and Mendez, I. (2001). Enhancement of sensorimotor behavioral recovery in hemiparkinsonian rats with intrastriatal, intranigral, and intrasubthalamic nucleus dopaminergic transplants. $J$. Neurosci. 21, 3521-3530. 
Murer, M. G., Ferrario, J., Delfino, M., Dziewczapolski, G., Gershanik, O. S., and Raisman-Vozari, R. (1999). Increased [125I] sulpiride binding in the subthalamic nucleus of rats with nigrostriatal lesions. Neuroreport 10, 1501-1505.

Murray, A. M., Ryoo, H. L., Gurevich, E., and Joyce, J. N. (1994). Localization of dopamine D3 receptors to mesolimbic and D2 receptors to mesostriatal regions of human forebrain. Proc. Natl. Acad. Sci. U.S.A. 91, 11271-11275.

Nambu, A., and Llinas, R. (1994). Electrophysiology of globus pallidus neurons in vitro. J. Neurophysiol. 72, 1127-1139.

Nambu, A., Takada, M., Inase, M., and Tokuno, H. (1996). Dual somatotopical representations in the primate subthalamic nucleus: evidence for ordered but reversed body-map transformations from the primary motor cortex and the supplementary motor area. J. Neurosci. 16, 2671-2683.

Nambu, A., Tokuno, H., Hamada, I., Kita, H., Imanishi, M., Akazawa, T., Ikeuchi, Y., and Hasegawa, N. (2000). Excitatory cortical inputs to pallidal neurons via the subthalamic nucleus in the monkey. J. Neurophysiol. 84, 289-300.

Nambu, A., Tokuno, H., and Takada, M. (2002). Functional significance of the cortico-subthalamo-pallidal 'hyperdirect' pathway. Neurosci. Res. 43, 111-117.

Napier, T. C., Simson, P. E., and Givens, B. S. (1991). Dopamine electrophysiology of ventral pallidal/substantia innominata neurons: comparison with the dorsal globus pallidus. $J$. Pharmacol. Exp. Ther. 258, 249-262.

Narang, N., and Wamsley, J. K. (1995). Time dependent changes in DA uptake sites, D1 and D2 receptor binding and mRNA after 6-OHDA lesions of the medial forebrain bundle in the rat brain. J. Chem. Neuroanat. 9, 41-53.

Neve, K. A. (ed.). (1997). The Dopamine Receptors. Totowa, NJ: Humana Press.

Ni, Z., Gao, D., Bouali-Benazzouz, R., Benabid, A. L., and Benazzouz, A. (2001). Effect of microiontophoretic application of dopamine on subthalamic nucleus neuronal activity in normal rats and in rats with unilateral lesion of the nigrostriatal pathway. Eur. J. Neurosci. 14, 373-381.

Nieoullon,A., Cheramy,A., and Glowinski, J. (1978). Release of dopamine evoked by electrical stimulation of the motor and visual areas of the cerebral cortex in both caudate nuclei and in the substantia nigra in the cat. Brain Res. 145, 69-83.

Nikkhah, G., Cunningham, M. G., Cenci, M. A., McKay, R. D., and Bjorklund,
A. (1995a). Dopaminergic microtransplants into the substantia nigra of neonatal rats with bilateral 6-OHDA lesions. I. Evidence for anatomical reconstruction of the nigrostriatal pathway. J. Neurosci. 15, 3548-3561.

Nikkhah, G., Cunningham, M. G., McKay, R., and Bjorklund, A. (1995b). Dopaminergic microtransplants into the substantia nigra of neonatal rats with bilateral 6-OHDA lesions. II. Transplant-induced behavioral recovery. J. Neurosci. 15, 3562-3570.

Nirenberg, M. J., Vaughan, R. A., Uhl, G. R., Kuhar, M. J., and Pickel, V. M. (1996). The dopamine transporter is localized to dendritic and axonal plasma membranes of nigrostriatal dopaminergic neurons. J. Neurosci. 16, 436-447.

Nutt, J. G., Burchiel, K. J., Comella, C. L., Jankovic, J., Lang, A. E., Laws, E. R. Jr., Lozano, A. M., Penn, R. D., Simpson, R. K. Jr., Stacy, M., and Wooten, G. F. (2003). Randomized, double-blind trial of glial cell line-derived neurotrophic factor (GDNF) in PD. Neurology 60, 69-73.

Olsson, M., Nikkhah, G., Bentlage, C., and Bjorklund, A. (1995). Forelimb akinesia in the rat Parkinson model: differential effects of dopamine agonists and nigral transplants as assessed by a new stepping test. J. Neurosci. 15, 3863-3875.

Overton, P. G., and Greenfield, S. A. (1995). Determinants of neuronal firing pattern in the guinea-pig subthalamic nucleus: an in vivo and in vitro comparison. J. Neural Transm. Park. Dis. Dement. Sect. 10, 41-54.

Palmer,M.R., Granholm,A.C., van Horne, C. G., Giardina, K. E., Freund, R. K., Moorhead, J. W., and Gerhardt, G. A. (2001). Intranigral transplantation of solid tissue ventral mesencephalon or striatal grafts induces behavioral recovery in 6-OHDA-lesioned rats. Brain Res. 890, 86-99.

Parent, A., and Hazrati, L. N. (1994). Multiple striatal representation in primate substantia nigra. J. Comp. Neurol. 344, 305-320.

Parent, A., and Hazrati, L. N. (1995a). Functional anatomy of the basal ganglia. I. The cortico-basal gangliathalamo-cortical loop. Brain Res. Brain Res. Rev. 20, 91-127.

Parent, A., and Hazrati, L. N. (1995b). Functional anatomy of the basal ganglia. II. The place of subthalamic nucleus and external pallidum in basal ganglia circuitry. Brain Res. Brain Res. Rev. 20, 128-154.

Parent, A., Lavoie, B., Smith, Y., and Bedard, P. (1990). The dopaminergic nigropallidal projection in primates: distinct cellular origin and relative sparing in MPTP-treated monkeys. Adv. Neurol. 53, 111-116.

Parent, A., Sato, F., Wu, Y., Gauthier, J., Levesque, M., and Parent, M. (2000). Organization of the basal ganglia: the importance of axonal collateralization. Trends Neurosci. 23, S20-S27.

Parent, A., and Smith, Y. (1987). Differential dopaminergic innervation of the two pallidal segments in the squirrel monkey (Saimiri sciureus). Brain Res. 426, 397-400.

Parent, A., Smith, Y., Filion, M., and Dumas, J. (1989). Distinct afferents to internal and external pallidal segments in the squirrel monkey. Neurosci. Lett. 96, 140-144.

Parent, M., Levesque, M., and Parent, A. (1999). The pallidofugal projection system in primates: evidence for neurons branching ipsilaterally and contralaterally to the thalamus and brainstem. J. Chem. Neuroanat. 16 , 153-165.

Parry, T. J., Eberle-Wang, K., Lucki, I., and Chesselet, M. F. (1994). Dopaminergic stimulation of subthalamic nucleus elicits oral dyskinesia in rats. Exp. Neurol. 128, 181-190.

Pavon-Fuentes, N., Macias-Gonzalez, R., Blanco-Lezcano, L., AlvarezGonzalez, L., Martinez-Marti, L. Castillo-Diaz, L., De La Cuetara Bernal, K., Diaz, C., Lorigados-Pedre, L., Coro, Y., Garcia-Varona, A. Y. Rosillo, J. C., and Diaz, E. (2002). Effects of simultaneous transplant of foetal mesencephalic cells in the striatum and the subthalamic nucleus of hemiparkinsonian rats. Rev. Neurol. 34, 917-923.

Pawlak, V., and Kerr, J. N. (2008). Dopamine receptor activation is required for corticostriatal spike-timing-dependent plasticity. J. Neurosci. 28, 2435-2446.

Picconi, B., Centonze, D., Hakansson, K., Bernardi, G., Greengard, P., Fisone, G. Cenci, M. A., and Calabresi, P. (2003). Loss of bidirectional striatal synaptic plasticity in L-DOPA-induced dyskinesia. Nat. Neurosci. 6, 501-506.

Pifl, C., Bertel, O., Schingnitz, G., and Hornykiewicz, O. (1990). Extrastriatal dopamine in symptomatic and asymptomatic rhesus-monkeys treated with 1-methyl-4-phenyl-1,2,3,6-tetrahydropyridine (MPTP). Neurochem. Int 17, 263-270.

Pifl, C., Schingnitz, G., and Hornykiewicz, O. (1992). Striatal and non-striatal neurotransmitter changes in MPTPparkinsonism in rhesus monkey: the symptomatic versus the asymptomatic condition. Neurochem. Int. 20(Suppl.), 295S-297S.

Porritt, M., Stanic, D., Finkelstein, D. Batchelor, P., Lockhart, S., Hughes, A. Kalnins, R., and Howells, D. (2005).
Dopaminergic innervation of the human striatum in Parkinson's disease. Mov. Disord. 20, 810-818.

Pucak, M. L., and Grace, A. A. (1994). Evidence that systemically administered dopamine antagonists activate dopamine neuron firing primarily by blockade of somatodendritic autoreceptors. J. Pharmacol. Exp. Ther. 271, 1181-1192.

Quik, M., Police, S., He, L., Di Monte, D. A., and Langston, J. W. (2000). Expression of $\mathrm{D}(3)$ receptor messenger RNA and binding sites in monkey striatum and substantia nigra after nigrostriatal degeneration: effect of levodopa treatment. Neuroscience 98, 263-273.

Radnikow, G., and Misgeld, U. (1998). Dopamine D1 receptors facilitate GABAA synaptic currents in the rat substantia nigra pars reticulata. $J$. Neurosci. 18, 2009-2016.

Raz, A., Frechter-Mazar, V., Feingold, A., Abeles, M., Vaadia, E., and Bergman, H. (2001). Activity of pallidal and striatal tonically active neurons is correlated in mptp-treated monkeys but not in normal monkeys. J. Neurosci. 21, RC128.

Raz, A., Vaadia, E., and Bergman, H. (2000). Firing patterns and correlations of spontaneous discharge of pallidal neurons in the normal and the tremulous 1-methyl-4-phenyl1,2,3,6-tetrahydropyridine vervet model of parkinsonism. J. Neurosci. 20, 8559-8571.

Reubi, J. C., and Sandri, C. (1979). Ultrastructural observations on intercellular contacts of nigral dendrites. Neurosci. Lett. 13, 183-188.

Rice, M. E., and Cragg, S. J. (2008). Dopamine spillover after quantal release: rethinking dopamine transmission in the nigrostriatal pathway. Brain Res. Rev. 58, 303-313.

Rice, M. E., Richards, C. D., Nedergaard, S., Hounsgaard, J., Nicholson, C., and Greenfield, S. A. (1994). Direct monitoring of dopamine and 5-HT release in substantia nigra and ventral tegmental area in vitro. Exp. Brain Res. 100, 395-406.

Richfield, E. K., Young, A. B., and Penney, J. B. (1987). Comparative distribution of dopamine D- 1 and D- 2 receptors in the basal ganglia of turtles, pigeons, rats, cats, and monkeys. J. Comp. Neurol. 262, 446-463.

Rinvik, E., Grofova, I., Hammond, C., Feger, J., and Deniau, J. M. (1979). "A study of the afferent connections to the subthalamic nucleus in the monkey and the cat using the HRP technique," in The Extrapyramidal System and Its Disorders, eds L. J. Poirier, T. L. Sourkes, and P. J. Bedard. (New York, NY: Raven Press), 53-70. 
Rivera, A., Trias, S., Penafiel, A., Angel Narvaez, J., Diaz-Cabiale, Z., Moratalla, R., and de la Calle, A. (2003). Expression of D4 dopamine receptors in striatonigral and striatopallidal neurons in the rat striatum. Brain Res. 989, 35-41.

Robertson, G.S., Damsma, G., and Fibiger, H. C. (1991). Characterization of dopamine release in the substantia nigra by in vivo microdialysis in freely moving rats. J. Neurosci. 11, 2209-2216.

Robledo, P., and Feger, J. (1990). Excitatory influence of rat subthalamic nucleus to substantia nigra pars reticulata and the pallidal complex: electrophysiological data. Brain Res. 518, 47-54.

Romanelli, P., Esposito, V., Schaal, D. W., and Heit, G. (2005). Somatotopy in the basal ganglia: experimental and clinical evidence for segregated sensorimotor channels. Brain Res. Brain Res. Rev. 48, 112-128.

Rommelfanger, K., Galvan, A., Kliem, M. A., Khan, Z. U., Smith, Y., and Wichmann, T. (2010). Subcellular localization and functional effects of dopamine receptors in the primate subthalamic nucleus. Int. Basal Ganglia Soc. Abstr. P-89.

Rosales, M. G., Martinez-Fong, D., Morales, R., Nunez, A., Flores, G., Gongora-Alfaro, J. L., Floran, B., and Aceves, J. (1997). Reciprocal interaction between glutamate and dopamine in the pars reticulata of the rat substantia nigra: a microdialysis study. Neuroscience 80, 803-810.

Rouaud, T., Lardeux, S., Panayotis, N., Paleressompoulle, D., Cador, M., and Baunez,C. (2010). Reducing the desire for cocaine with subthalamic nucleus deep brain stimulation. Proc. Natl. Acad. Sci. U.S.A. 107, 1196-1200.

Ruskin, D. N., Bergstrom, D. A., and Walters, J. R. (2002). Nigrostriatal lesion and dopamine agonists affect firing patterns of rodent entopeduncular nucleus neurons. J. Neurophysiol. $88,487-496$.

Santiago, M., and Westerink, B.H. (1991). Characterization and pharmacological responsiveness of dopamine release recorded by microdialysis in the substantia nigra of conscious rats. $J$. Neurochem. 57, 738-747.

Santiago, M., and Westerink, B. H. (1992). Simultaneous recording of the release of nigral and striatal dopamine in the awake rat. Neurochem. Int.20(Suppl.), 107S-110S.

Sanudo-Pena, M. C., and Walker, J. M. (1998). Effects of intrapallidal cannabinoids on rotational behavior in rats: interactions with the dopaminergic system. Synapse 28, 27-32.

Schneider, J. S., and Dacko, S. (1991). Relative sparing of the dopaminergic innervation of the globus pallidus in monkeys made hemi-parkinsonian by intracarotid MPTP infusion. Brain Res. 556, 292-296.

Schultz, W. (2007). Behavioral dopamine signals. Trends Neurosci. 30, 203-210.

Shen, K. Z., and Johnson, S. W. (2000). Presynaptic dopamine D2 and muscarine $\mathrm{M} 3$ receptors inhibit excitatory and inhibitory transmission to rat subthalamic neurones in vitro. J. Physiol. (Lond.) 525(Pt 2), 331-341.

Shin, R. M., Masuda, M., Miura, M., Sano, H.,Shirasawa, T.,Song,W.J., Kobayashi, K., and Aosaki, T. (2003). Dopamine D4 receptor-induced postsynaptic inhibition of GABAergic currents in mouse globus pallidus neurons. $J$. Neurosci. 23, 11662-11672.

Shink, E., Bevan, M. D., Bolam, J. P., and Smith, Y. (1996). The subthalamic nucleus and the external pallidum: two tightly interconnected structures that control the output of the basal ganglia in the monkey. Neuroscience 73, 335-357.

Sidibe, M., and Smith, Y. (1996). Differential synaptic innervation of striatofugal neurones projecting to the internal or external segments of the globus pallidus by thalamic afferents in the squirrel monkey. J. Comp. Neurol. 365, 445-465.

Slevin, J. T., Gerhardt, G. A., Smith, C. D., Gash, D. M., Kryscio, R., and Young, B. (2005). Improvement of bilateral motor functions in patients with Parkinson disease through the unilateral intraputaminal infusion of glial cell line-derived neurotrophic factor. J. Neurosurg. 102, 216-222.

Smith, Y., Hazrati, L. N., and Parent, A. (1990). Efferent projections of the subthalamic nucleus in the squirrel monkey as studied by the PHA-L anterograde tracing method. J. Comp. Neurol. 294, 306-323.

Smith, Y., and Kieval, J. Z. (2000). Anatomy of the dopamine system in the basal ganglia. Trends Neurosci. 23, S28-S33.

Smith, Y., Lavoie, B., Dumas, J., and Parent, A. (1989). Evidence for a distinct nigropallidal dopaminergic projection in the squirrel monkey. Brain Res. 482, 381-386.

Smith, Y., and Parent, A. (1988). Neurons of the subthalamic nucleus in primates display glutamate but not GABA immunoreactivity. Brain Res. 453, 353-356.

Smith, Y., Raju, D., Nanda, B., Pare, J. F., Galvan, A., and Wichmann, T. (2009). The thalamostriatal systems: anatomi$\mathrm{cal}$ and functional organization in normal and parkinsonian states. Brain Res. Bull. 78, 60-68.

Smith, Y., and Villalba, R. (2008). Striatal and extrastriatal dopamine in the basal ganglia: an overview of its anatomical organization in normal and Parkinsonian brains. Mov. Disord. 23(Suppl. 3), S534-S547.

Stamford, J. A., Kruk, Z. L., Palij, P., and Millar, J. (1988). Diffusion and uptake of dopamine in rat caudate and nucleus accumbens compared using fast cyclic voltammetry. Brain Res. 448, 381-385.

Starr, P. A., Rau, G. M., Davis, V., Marks, W. J. Jr., Ostrem, J. L., Simmons, D. Lindsey, N., and Turner, R. S. (2005). Spontaneous pallidal neuronal activity in human dystonia: comparison with Parkinson's disease and normal macaque. J. Neurophysiol. 93 3165-3176.

Starr, P. A., Wichmann, T., van Horne, C., and Bakay, R. A. (1999). Intranigral transplantation of fetal substantia nigra allograft in the hemiparkinsonian rhesus monkey. Cell Transplant. 8, 37-45.

Stowe, R. L., Ives, N. J., Clarke, C., van Hilten, J., Ferreira, J., Hawker, R. J., Shah, L., Wheatley, K., and Gray, R. (2008). Dopamine agonist therapy in early Parkinson's disease. Cochrane Database Syst. Rev. CD006564.

Sugimoto, T., Hattori, T., Mizuno, N. Itoh, K., and Sato, M. (1983). Direct projections from the centre medianparafascicular complex to the subthalamic nucleus in the cat and rat. $J$. Comp. Neurol. 214, 209-216.

Sunahara, R. K., Guan, H. C., O’Dowd, B. F., Seeman, P., Laurier, L. G., Ng, G., George, S. R., Torchia, J., Van Tol, H. H., and Niznik, H. B. (1991). Cloning of the gene for a human dopamine D5 receptor with higher affinity for dopamine than D1. Nature 350 614-619.

Svenningsson, P., and Le Moine, C. (2002) Dopamine D1/5 receptor stimulation induces c-fos expression in the subthalamic nucleus: possible involvement of local D5 receptors. Eur. J. Neurosci. $15,133-142$.

Takada, M., Tokuno, H., Hamada, I., Inase, M., Ito, Y., Imanishi, M., Hasegawa, N., Akazawa, T. Hatanaka, N., and Nambu, A. (2001). Organization of inputs from cingulate motor areas to basal ganglia in macaque monkey. Eur. J. Neurosci. 14 1633-1650.

Tiberi, M., and Caron, M. G. (1994).High agonist-independent activity is a distinguishing feature of the dopamine D1B receptor subtype. J. Biol. Chem. 269, 27925-27931.

Timmerman, W., and Abercrombie, E. D. (1996).Amphetamine-induced release of dendritic dopamine in substantia nigra pars reticulata: D1-mediated behavioral and electrophysiological effects. Synapse 23, 280-291.
Timmerman, W., and Westerink, B. H. (1995). Extracellular gamma-aminobutyric acid in the substantia nigra reticulata measured by microdialysis in awake rats: effects of various stimulants. Neurosci. Lett. 197, 21-24.

Tremblay, L., Filion, M., and Bedard, P. J. (1989). Responses of pallidal neurons to striatal stimulation in monkeys with MPTP-induced parkinsonism. Brain Res. 498, 17-33.

Trevitt, J. T., Carlson, B. B., Nowend, K., and Salamone, J.D. (2001). Substantia nigra pars reticulata is a highly potent site of action for the behavioral effects of the D1 antagonist SCH 23390 in the rat. Psychopharmacology (Berl.) 156, 32-41.

Trevitt, T., Carlson, B., Correa, M., Keene, A., Morales, M., and Salamone, D. (2002). Interactions between dopamine D1 receptors and gammaaminobutyric acid mechanisms in substantia nigra pars reticulata of the rat: neurochemical and behavioral studies. Psychopharmacology (Berl.) 159, 229-237.

Truong, D.D., Bhidayasiri, R., and Wolters, E. (2008). Management of non-motor symptoms in advanced Parkinson disease. J. Neurol. Sci. 266, 216-228.

Twery, M. J., Thompson, L. A., and Walters, J. R. (1994). Intracellularly recorded response of rat striatal neurons in vitro to fenoldopam and SKF 38393 following lesions of midbrain dopamine cells. Synapse 18, 67-78.

Uslaner, J. M., and Robinson, T.E. (2006). Subthalamic nucleus lesions increase impulsive action and decrease impulsive choice - mediation by enhanced incentive motivation? Eur. J. Neurosci. 24, 2345-2354.

Wang, Z., Kai, L., Day, M., Ronesi, J., Yin, H. H., Ding, J., Tkatch, T., Lovinger D. M., and Surmeier, D. J. (2006). Dopaminergic control of corticostriatal long-term synaptic depression in medium spiny neurons is mediated by cholinergic interneurons. Neuron 50, 443-452.

Wassef, M., Berod, A., and Sotelo, C. (1981). Dopaminergic dendrites in the pars reticulata of the rat substantia nigra and their striatal input. Combined immunocytochemical localization of tyrosine hydroxylase and anterograde degeneration. Neuroscience 6, 2125-2139.

Waszczak, B. L. (1990). Differential effects of D1 and D2 dopamine receptor agonists on substantia nigra pars reticulata neurons. Brain Res. 513, 125-135.

Westerink, B. H. C., Deboer, P., Santiago, M., and Devries, J. B. (1994). Do nerveterminals and cell-bodies of nigrostriatal dopaminergic-neurons of the rat contain similar receptors. Neurosci. Lett. 167, 109-112. 
Whone, A. L., Moore, R. Y., Piccini, P. P., and Brooks, D. J. (2003). Plasticity of the nigropallidal pathway in Parkinson's disease. Ann. Neurol. 53, 206-213.

Wichmann, T., and Delong, M. R. (2007). Anatomy and physiology of the basal ganglia: relevance to Parkinson's disease and related disorders. Handb. Clin. Neurol. 83, 1-18.

Wickens, J. R., Reynolds, J. N., and Hyland, B. I. (2003). Neural mechanisms of reward-related motor learning. Curr. Opin. Neurobiol. 13, 685-690.

Windels, F., and Kiyatkin, E. A. (2006). Dopamine action in the substantia nigra pars reticulata: iontophoretic studies in awake, unrestrained rats. Eur. J. Neurosci. 24, 1385-1394.
Wirtshafter, D., and Asin, K. E. (1995). Dopamine antagonists induce foslike-immunoreactivity in the substantia nigra and entopeduncular nucleus of the rat. Brain Res. 670, 205-214.

Yasukawa, T., Kita, T., Xue, Y., and Kita, H. (2004). Rat intralaminar thalamic nuclei projections to the globus pallidus: a biotinylated dextran amine anterograde tracing study. J. Comp. Neurol. 471, 153-167.

Yung, K. K., Bolam, J. P., Smith, A. D., Hersch, S. M., Ciliax, B. J., and Levey, A. I. (1995). Immunocytochemical localization of D1 and D2 dopamine receptors in the basal ganglia of the rat: light and electron microscopy. Neuroscience 65, 709-730.
Yurek,D.M. (1997). Intranigral transplants of fetal ventral mesencephalic tissue attenuate D1-agonist-induced rotational behavior. Exp. Neurol. 143, 1-9.

Yurek, D. M., and Hipkens, S. B. (1993) Intranigral injections of SCH 23390 inhibit amphetamine-induced rotational behavior. Brain Res. 623, 56-64.

Zhu, Z. T., Shen, K. Z., and Johnson, S. W. (2002). Pharmacological identification of inward current evoked by dopamine in rat subthalamic neurons in vitro. Neuropharmacology 42, 772-781.

Conflict of Interest Statement: The authors declare that the research was conducted in the absence of any com- mercial or financial relationships that could be construed as a potential conflict of interest.

Received: 30 July 2010; accepted: 23 September 2010; published online: 27 October 2010.

Citation: Rommelfanger KS and Wichmann $T$ (2010) Extrastriatal dopaminergic circuits of the basal ganglia. Front. Neuroanat. 4:139. doi: 10.3389/fnana.2010.00139

Copyright (C) 2010 Rommelfanger and Wichmann. This is an open-access article subject to an exclusive license agreement between the authors and the Frontiers Research Foundation, which permits unrestricted use, distribution, and reproduction in any medium, provided the original authors and source are credited. 